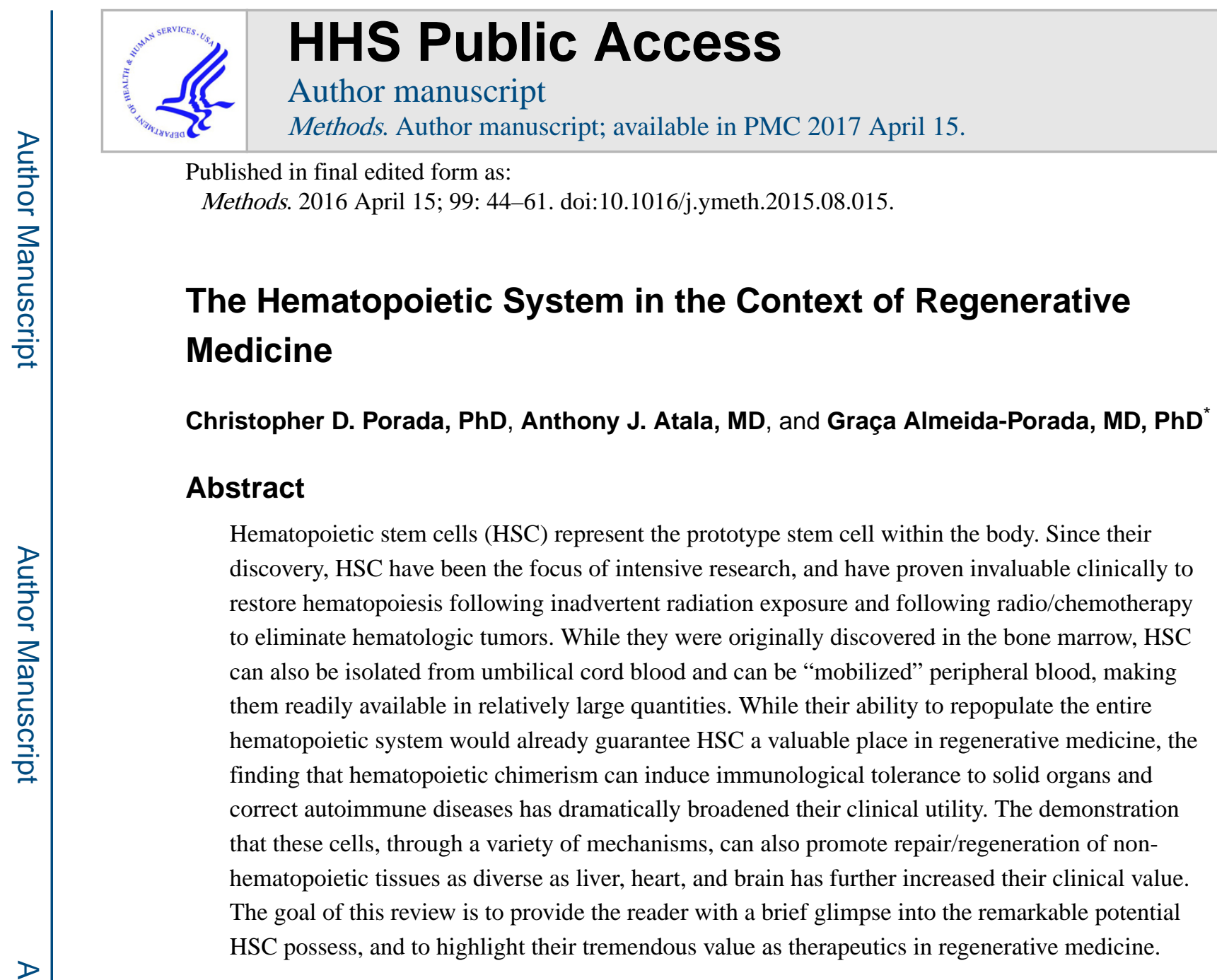

\title{
Keywords
}

hematopoietic stem cell (HSC); transplantation; bone marrow; alternate sources of HSC; HSC for repairing non-hematopoietic tissues; HSC for tolerance induction

\section{Introduction/Historical Perspective}

When scientists discovered that a rare population of stem cells present within the bone marrow maintains the entire adult hematopoietic system, the door was opened to the possibility of applying regenerative medicine to the field of hematology.

The diverse array of hematopoietic cells circulating within the peripheral blood at any given point is produced within the bone marrow through the exquisitely coordinated process of

\footnotetext{
"To whom Correspondence should be addresed: Graça Almeida-Porada, MD, PhD, Professor of Regenerative Medicine, Wake Forest Institute for Regenerative Medicine, Wake Forest University School of Medicine, 391 Technology Way, Winston-Salem, NC 27157-1083, Unites States of America, galmeida@wakehealth.edu.

Christopher D. Porada, Ph.D., Associate Professor of Regenerative Medicine, Wake Forest Institute for Regenerative Medicine, 391

Technology Way, Winston-Salem, NC 27157-1083, cporada@wakehealth.edu

Anthony J. Atala, M.D., Professor of Regenerative Medicine, Director, Wake Forest Institute for Regenerative Medicine, 391

Technology Way, Winston-Sale, NC 27157-1083, aatala@wakehealth.edu

Publisher's Disclaimer: This is a PDF file of an unedited manuscript that has been accepted for publication. As a service to our customers we are providing this early version of the manuscript. The manuscript will undergo copyediting, typesetting, and review of the resulting proof before it is published in its final citable form. Please note that during the production process errors may be discovered which could affect the content, and all legal disclaimers that apply to the journal pertain.
} 
hematopoiesis. Remarkably, under steady-state conditions, this process generates roughly ten billion red blood cells and one billion white blood cells every hour of every day during the lifetime of a human, while simultaneously ensuring that the levels of each cell lineage within the circulation are maintained within precisely regulated limits. In addition to supplying all these cells during steady state, the bone marrow rapidly responds to demands, increasing the production of specific blood cells to counter a variety of insults and injuries, thus ensuring homeostasis is quickly restored.

Adult hematopoiesis is supported by rare hematopoietic stem cells (HSC) that account for only about $0.01 \%$ of the total cells in the bone marrow [1]. The complex hematopoietic process is orchestrated by the bone marrow microenvironment, which provides a network of extracellular matrix, vasculature, and stromal cells that supply the support/factors necessary for HSC survival, division, and differentiation. There are two distinct HSC niches within the marrow, the osteoblastic and the perivascular. A good deal of controversy exists as to whether HSC selectively reside in one or the other of these niches, and a great deal of interest is currently focused on interrogating the perivascular niche, which is frequently located close to trabecular bone, and is comprised of mesenchymal stromal cells (MSC) and endothelial cells [2-10].

Although many reviews of the HSC field do not make mention of it, it is important to note that some of the first compelling evidence that stem/progenitor are present in the bone marrow, and that damage to the chromatin of these primitive cells could explain the pronounced effects radiation exerted upon hematopoiesis, came from studies performed as early as the 1930s by Florence Sabin [11, 12]. Later, in the 1950s, Nobel laureate E. Donnall Thomas conducted pioneering work on identical twins that clearly demonstrated that primitive stem-like hematopoietic cells were present within the bone marrow, and that these cells had the ability to restore hematopoiesis after lethal irradiation [13]. However, it was the pivotal series of studies conducted by Till and McCulloch in the 1960s that provided the definitive proof for the existence of the multipotent, self-renewing, serially transplantable HSC within normal mouse hematopoietic tissue [14, 15]. Collectively, these studies established the clonal nature of hematopoiesis, and introduced the concept that transplanting a single multipotent HSC can regenerate the entire hematopoietic system within a suitable recipient.

\section{HSC Transplantation for Hematologic Diseases/Disorders}

The fact that the entire hematopoietic system can be repopulated following infusion of limited numbers of HSC makes it possible for HSC transplantation to treat/cure a range of hematologic diseases, including malignancies.

Following detonation of the first atomic bombs, physicians and scientists eagerly sought ways to protect the hematopoietic system from the life-threatening effects of ionizing radiation, and to develop treatments to restore this critical system following exposure. Jacobson and colleagues were the first to report that shielding the spleen or femur of mice with lead protected the mice from the lethal effects of ionizing radiation on blood production. Interestingly, at the time, the observed protection was interpreted to be due to 
the production of some unknown factor within the spleen and marrow that stimulated recovery/regeneration of the hematopoietic system [16]. However, a series of studies performed by Lorenz et al., Barnes and Loutit, and Main and Prehn [17-23] rapidly disproved this mistaken notion by showing that radio-protection could also be conferred by intravenous infusions of bone marrow, and by providing definitive evidence that the observed radio-protection was, in fact, due to HSC that were present within the infused marrow. These groundbreaking observations began the era of HSC transplantation, bringing the hope/dream that this new treatment could ultimately cure patients with life-threatening hematological malignancies by allowing physicians to escalate radiation doses to levels that would completely ablate the marrow, and thus ensure killing of all of the cancer cells, and to then rescue the patient by infusing bone marrow cells from a healthy donor to restore normal blood production.

A number of successes were quickly achieved in mouse models of bone marrow transplantation (BMT), which created a great deal of optimism in the field, and quickly led to premature attempts to translate this promising new therapy into the clinic. Thomas and colleagues at the Columbia University-affiliated Mary Imogene Bassett Hospital (and later at the Fred Hutchinson Cancer Research Center (FHCRC)) spearheaded many of these early efforts. They began their human HSC transplant program in the 1950s, and quickly proved that fairly large volumes of bone marrow could safely be infused into the circulation of human patients, and subsequently produce hematopoietic engraftment/repopulation, although this engraftment was transient in nature [13]. Within only a few years, this same group reported on the treatment of two acute lymphoblastic leukemia (ALL) patients, using high-dose total body irradiation (TBI) to kill the leukemic cells, followed by an infusion of bone marrow from twin (syngeneic) siblings to rescue the hematopoietic system of these patients [24]. Concurrently, the renowned French oncologist, George Mathé, performed the first European allogeneic BMTs, in the hopes of saving the lives of five Yugoslavian workers who had accidentally been exposed to high-dose radiation as a result of a Criticality accident at the Vinča Nuclear Institute. This report is particularly interesting, because four of the five recipients survived, despite exhibiting only partial and transient chimerism. In retrospect, it appears their survival was most likely due to limited numbers of surviving autologous HSC reconstituting hematopoiesis while under the support/protection of the infused allogeneic marrow cells [25-27]. In another contemporaneous study, McGovern et al. [28] successfully reconstituted a terminal ALL patient with autologous bone marrow cells that had been harvested during a previous remission and cryopreserved prior to infusion.

Collectively, these studies provided convincing proof that infusing bone marrow cells could protect against irradiation-induced bone marrow damage/destruction and mediate rapid clinical and hematological recovery. However, these studies also revealed that even supralethal doses of irradiation were not sufficient to eliminate hematologic malignancies, and results of most clinical BMT attempts in patients with leukemia and lymphomas were largely disappointing $[25,29]$. These discouraging outcomes likely stem from the fact that all of the preclinical BMT studies were performed in inbred mice, which are genetically identical, and therefore require no immunological matching between donor and recipient [30]. In contrast, with the exception of the study Thomas performed in twins, all other clinical BMTs had used cells isolated from allogeneic donors, which unknowingly 
introduced two major immunological challenges that do not exist in inbred mice: 1) the recipient's immune system rejecting the grafted cells, which leads to graft failure; and 2) graft-versus-host disease (GVHD), in which host-reactive donor T lymphocytes attack the recipient's skin, liver, and gastrointestinal tract, causing damage that, if left unchecked, can be fatal [31,32]. These initial clinical failures led many investigators to conclude that the immunological barriers posed by transplanting bone marrow cells from one individual to another would prove insurmountable, and that BMT would not likely ever be used in clinical medicine to treat hematological malignancies [30].

Thomas' group, however, was not dissuaded by these clinical setbacks, and they began work in earnest to learn how to overcome the host-recipient immune barrier. Their Nobel prizewinning studies in the dog model led to the development of new methods of bone marrow cell isolation and host immunosuppression, and novel agents to combat graft rejection. Perhaps most importantly, this group also developed a canine histocompatibility typing system, which enabled them to show that, to reduce the risks of both graft rejection and of GVHD, it was essential to have histocompatibility matching between donor and recipient [33-66]. These studies in the canine model led to a marked improvement in the understanding of the human major histocompatibility complex (HLA), making matching possible in human patients [29]. They also revealed, however, that GVHD can still pose a serious problem for a well-matched donor and recipient, unless specific immunosuppressive agents to block T lymphocyte proliferation are administered [29, 39, 44, 57-62, 67-70].

Once it was recognized that GVHD was caused by T lymphocytes present within the HSC graft, multiple groups tested T lymphocyte depletion or immunoselection of HSC, and showed that both methods of graft manipulation markedly reduced the risk of GVHD following allogeneic $\mathrm{HSC}$ transplantation [71, 72]. Equally as exciting, investigators came to the realization that, by performing immunoselection to enrich for $\mathrm{HSC}$, it was possible to use autologous HSC for hematological malignancies, because this immunoselection could result in a 30- to 50-fold reduction in tumor burden within the graft [73-76]. Unfortunately, however, it was soon discovered that these benefits came at a very high price, since grafts that had been T-depleted or immunoselected often engrafted less effectively/were rejected and, in the case of the immunoselected grafts, the time to reconstitution was significantly prolonged, placing patients at risk of significant hematologic morbidities and opportunistic infection [77-81]. Luckily, during this same time period, advances in infectious disease therapeutics provided new means of protecting the recipient during this prolonged period of vulnerability [82-84].

Somewhat unexpectedly, more detailed analyses of emerging preclinical and clinical data revealed that allogeneic HSC transplantation could also produce a second potent therapeutic effect — the so-called graft-versus-tumor (GVT) effect — in which donor lymphocytes present in the graft recognize and kill the host's tumor cells. Barnes' group showed that leukemic cells were eradicated when mice received allogeneic, but not syngeneic, BMT, demonstrating this important GVT effect for the first time [85, 86]. These investigators then had the insight to propose that cells within the graft could mount an immune response against the host leukemia, and might thus play a critical part in killing cancer cells. In 1965, Mathé achieved the first survival of an allogeneic bone marrow graft in a leukemia patient, 
and showed that the graft produced an anti-leukemic effect he termed "adoptive immunotherapy" [23, 25].

Disappointingly, as more transplant data became available, physicians recognized that patients who developed GVHD were much less likely to suffer cancer relapse [87-89], and it was soon revealed that GVHD and GVT were intimately linked. As a result, while T lymphocyte depletion and immunoselection of HSC could dramatically reduce the incidence of GVHD, these manipulations would inexorably remove the ability of the infused marrow cells to mediate the critically important GVT effect, profoundly increasing the patient's risk of relapse [77, 80, 81, 90-95]. Similarly, Kolb and colleagues (in 1990) became the first to show that it was possible to successfully induce remission in 3 patients with relapsed chronic myelogenous leukemia (CML) following an allogeneic transplant, by infusing donor lymphocytes (DLI) [96]. However, just as occurred transplants in which the initial graft contained high levels of T cells, two of these three patients developed GVHD following DLI.

Not surprisingly, the conventional HSC transplantation procedure using high-intensity radiation/chemotherapy to ablate the patient's endogenous marrow, poses serious risks and side effects, restricting the therapy to relatively young patients who are in good medical condition. As such, this potentially life-saving therapy cannot be used to treat some of the most common hematological disorders, for which the median age at diagnosis ranges from 65-70 years [23]. Fortunately, the discovery of the GVT effect made possible the development of the newer "reduced-intensity transplant" protocols, which do not destroy host HSC [97-103]. In contrast to a traditional allogeneic HSC transplant, this ingenious approach relies on the GVT effects of the graft, rather than the myeloablative effects of irradiation/chemotherapy, to kill cancer cells. Patients receive non-myeloablative irradiation, immunosuppressive drugs, and HSC transplantation, producing mixed hematopoietic chimerism. If the patient does not experience GVHD, he/she can then be infused with additional donor lymphocytes to promote conversion to completely donor-derived hematopoiesis, with the goal of inducing a robust GVT effect and complete eradication of the malignancy. The GVT effects are slow, with remission in some patients taking many months to achieve, but have produced very promising clinical results thus far. In addition, the lack of regimen-related toxicity now allows HSC transplantation to be performed in elderly/very sick patients who cannot be subjected to high levels of irradiation, and were thus ineligible for a transplant. Importantly, studies have now provided evidence that the GVT effect also makes it possible to combat metastatic tumors arising in other nonhematopoietic organs. Currently, researchers are focusing on better understanding the precise T lymphocyte populations responsible for GVHD and GVT, in the hopes of finding ways to induce a robust GVT effect without inducing GVHD.

\section{Alternate Sources of HSC}

Although HSC were first identified in and isolated from bone marrow, alternate sources of HSC such as mobilized peripheral blood and umbilical cord blood have many characteristics that make them well suited for clinical use. Moreover, with the advent of reprogramming technology, the development of methods to generate functional HSC from iPS cells promises 
to one day make it possible to generate unlimited numbers of perfectly matched, patientspecific HSC for therapy.

\subsection{Mobilized Peripheral Blood}

In the early days of HSC transplantation, the only graft source available was bone marrow, which was harvested from the pelvis or sternum under general anesthesia. While investigators were fine-tuning the details of conditioning regimens and graft composition, persuasive evidence emerged that a strong correlation existed between the absolute number of HSC present within bone marrow graft transplanted and the robustness of hematopoietic engraftment. Increasing the dose of HSC also resulted in significantly lower mortality from infectious complications post-transplant [104]. This realization led to the search for means of increasing the number of HSC that could be harvested for transplant.

Studies in the 1970s-80s revealed that administering Pyran Copolymer to mice or dogs caused primitive colony-forming HSC to "mobilize" from the marrow into the circulation $[105,106]$. Moreover, the dose and the number of times/frequency with which Pyran Copolymer was administered directly affected the resultant levels of circulating HSC, leading the authors to conclude that mobilized peripheral blood (mPB) represented a viable source of HSC for transplantation [105-107]. Subsequent studies showed that hematopoietic cytokines could mobilize primitive HSC with long-term repopulating ability into the peripheral blood with relatively high efficiency [108], and that immunoisolation could be used to obtain highly enriched primitive HSC from this cytokine-mobilized human peripheral blood, thereby removing malignant cells and making it possible to use autologous cells to treat hematologic malignancies [109-113]. The non-invasiveness and ease with which $\mathrm{mPB}$ could be collected (compared to bone marrow harvest), and the discovery that HSC were present at higher frequency in these mobilized products than in steady-state bone marrow quickly led multiple laboratories/centers around the world to begin replacing bone marrow with mPB in the clinical setting [114-119]. Indeed, the use of mPB as an HSC source has dramatically increased over the past 15 years or so, and now accounts for $\sim 75 \%$ of HSC transplants from unrelated adult donors [104] and 99\% of autologous HSC transplants [120].

Interestingly, this dramatic shift has taken place without any hard clinical data to support the superiority of $\mathrm{mPB}$, in terms of better patient outcome or safety [104], and despite concerns that the higher T-cell content of mPB might lead to higher GVHD risk [115, 121-124]. Support for this shift has come from numerous large, multicenter, randomized trials performed to-date, which have collectively shown that engraftment/reconstitution is often faster and more robust with $\mathrm{mPB}$ than with marrow, and may be associated with a decreased relapse rate, but this appears to depend upon the patient population and malignancy in question $[125,126]$. However, as originally feared, these studies have also revealed that the use of $\mathrm{mPB}$ is associated with a significantly higher rate of chronic (and perhaps acute) GVHD than marrow, and offers no significant improvement in survival [114, 115, 124, 127137].

Nevertheless, it has recently been suggested [104] that specific characteristics of the patients may dictate which source of the HSC graft is best. For example, cancer patients who have 
never undergone cytotoxic chemotherapy, and may thus be at increased risk for graft failure/ rejection, might benefit from the use of $\mathrm{mPB}$, given its ability to mediate more robust engraftment [138-141]. Similarly, patients over the age of 50, and those with serious coexisting diseases, are now routinely conditioned with reduced-intensity regimens for transplants. Since these milder conditioning regimens provide less intensive immunosuppression, the more vigorous engraftment potential associated with $\mathrm{mPB}$ transplantation could potentially be advantageous. On the other hand, given its reduced propensity to induce GVHD, bone marrow may be better most other patients, particularly those who are immunosuppressed from prior chemotherapy, since this suppression should lower the risk of graft rejection. Interestingly, studies by Morton and colleagues have shown that bone marrow collected after treatment with growth factors, i.e., mobilized bone marrow, may possess the same enhanced engraftment potential as $\mathrm{mPB}$, but still retain the lower propensity to induce GVHD normally seen with steady-state bone marrow [129]. However, these exciting initial results will need to be rigorously tested in well-designed randomized clinical trials comparing this HSC source with unstimulated bone marrow or mobilized peripheral blood.

\subsection{Umbilical Cord Blood}

Although the concept of using umbilical cord blood (UCB) as a potential source of HSC for transplantation first appeared in the scientific literature in 1972 [142], a decade passed before Makio Ogawa reported [143] the presence within human UCB of a unique class of primitive hematopoietic colony-forming cells that, upon replating, had the ability to robustly generate secondary colonies, including multipotential colonies. This report prompted numerous groups to begin examining UCB as a potential source of HSC for transplantation, but it was the pivotal work of Hal Broxmeyer that ultimately made it possible for UCB to move from the laboratory to clinical practice [144-146].

The first HSC transplant using UCB was performed in 1988 in a 5-year old patient with severe aplastic anemia due to Fanconi Anemia (FA) [147]. This first UCB transplant required a tremendous collaborative effort between Arleen Auerbach, at the Rockefeller University, who had developed a method for accurate prenatal diagnosis of Fanconi anemia (FA) [148, 149], Hal Broxmeyer, at Indiana University, who had systematically analyzed the number of hematopoietic cell progenitors in cord blood with the ultimate goal of reconstituting hematopoiesis in humans [144, 146], and Eliane Gluckman, from Paris (France), who had shown that the in vivo hypersensitivity of FA cells to alkylating agents made it possible to successfully use attenuated dose conditioning in FA patients [150].

The UCB was collected during the birth of the healthy (confirmed in utero) sibling, cryopreserved, transported from Indiana to Paris in liquid nitrogen, thawed with no further processing, and transplanted into the preconditioned patient. The first signs of engraftment appeared on day 22, and gave way to complete hematological reconstitution and donor chimerism. The patient never developed GVHD, and is currently (>20 years post UCB transplant) healthy with complete long-term hematological and immunological donor reconstitution [147, 151]. This first successful transplant began a whole new era in allogeneic HSC transplantation, demonstrating that: 1) a single cord contained enough HSC 
to reconstitute hematopoiesis; 2) UCB could safely be collected at birth; and 3) UCB HSC could be cryopreserved and thawed without negatively affecting their repopulating ability [145].

In the years following this first successful transplant, UCB has become one of the more commonly used sources of HSC for allogeneic transplantation. While much of the original interest in cord blood was due to the possibility that it could be routinely collected at birth and cryopreserved for autologous use later in life (if needed), if the need arose, cord blood was soon found to exhibit many characteristics that make it an ideal HSC source. The first of these is its ready availability. A global network of cord blood banks has been established worldwide that has enabled the collection, cryopreservation, and distribution of over 600,000 UCB units to-date [152]. Because UCB is donated in advance and banked, all routine testing has been completed, eliminating the long delay that is inherent to the use of marrow as a graft.

In addition to its ready availability, the relative immaturity of the immune cells present in unrelated UCB are far less likely to cause GVHD than their counterparts in marrow or mPB. As a result, in marked contrast to marrow and $\mathrm{mPB}$, perfect HLA-matching is not necessary between donor and recipient for a UCB transplant to be successful. As a result, the patient's chance of finding a suitable donor is greatly increased. It is also important to note that UCB is far less likely than marrow or mPB to transmit common viruses like EBV and CMV, which can be lethal for transplant recipients.

However, along with all of these benefits come several shortcomings that have yet to be fully resolved. It is now apparent that the immaturity of the cells present within UCB represents a double-edged sword. While their immaturity reduces GVHD, it also significantly delays engraftment/repopulation, lengthening hospital stays, and placing the patient at risk of serious complications [153]. A second problematic issue with UCB is the limited volume that can be collected and the resultant small absolute number of HSC. While a typical UCB unit has ample cells to repopulate a newborn/child, there are usually insufficient numbers of HSC to successfully repopulate larger/higher weight adolescents and adults [145, 154]. This has largely limited the use of UCB as a graft to pediatric patients.

Two approaches have been taken to address the limited cell numbers in UCB. The first is to transplant multiple UCB units into the same recipient to bring the total nucleated cell number up to the required threshold for engraftment. This approach has proven to be successful from the standpoint of achieving successful engraftment. However, studies have suggested that the use of multiple cord blood units may be associated with increased GVHD [155], and have revealed an interesting phenomenon: when multiple UCB units are transplanted, both contribute to initial engraftment/recovery, but it is the HSC from only a single UCB unit that dominate hematopoiesis and ultimately produce long-term durable hematopoietic engraftment, with the cells from the other UCB units being lost over time $[156,157]$.

The second approach investigators are pursuing to combat the limited number of HSC within a typical UCB unit is ex-vivo expansion/manipulation to enhance numbers and/or potency of 
the cells collected from UCB and their engrafting capability. A number of new procedures have been attempted to achieve this goal, including various cytokine cocktails [158-160], novel matrices such as nanofibers [161-163], copper chelating agents [164, 165], transcriptional activators and inhibitors [166-176], and feeder layers often consisting of MSC and/or endothelial cells [177-183]. While these methods have all demonstrated that it is possible to significantly expand committed progenitor cells in vitro, with the exception of studies employing a feeder layer [177-183] (which would obviously complicate translation to the clinical arena), the ability to expand true long-term repopulating HSC present within UCB remains an elusive target [184-186] that is the subject of intense investigation, with recent advances suggesting this goal could be achieved in the near future [187].

\section{3 iPS and ES-derived HSC}

The recent discovery that somatic mammalian cells can be epigenetically reprogrammed to the hematopoietic lineage either by passage through a pluripotent state or directly [1-5], has raised the exciting possibility of generating patient-specific blood cells, and promises to achieve the ultimate Holy Grail in hematology - production of large numbers of healthy autologous HSC for transplantation. The ability to generate patient-specific HSC from nonhematopoietic cells would eliminate the risks associated with the use of allogeneic cells and simultaneously avoid the danger of relapse that is inherent to the use of autologous hematopoietic cells in patients with hematological malignancies.

Despite this great promise and intense efforts [188-195], however, studies thus far [194207] have revealed that it is not a trivial matter to generate functional HSC from pluripotent cells such as ES and iPS cells. Although cells that appear phenotypically to be hematopoietic stem/progenitor cells can be generated, the efficiency of this process is extremely low, making it unlikely that the numbers of HSC that would be required to repopulate a patient could be generated with current technology. A bigger problem that has become apparent is that the hematopoietic cells generated by forced differentiation of human iPS and ES cells do not pass the "gold standard" test for HSC functionality; that is, they do not provide longterm multilineage engraftment upon transplantation into suitable xenogeneic recipients [189, 194, 206-208]. In addition, hematopoietic stem/progenitor cells generated via reprogramming (either via an iPS intermediate or through direct reprogramming of fibroblasts) often exhibit lineage skewing when they differentiate in vivo, likely due to incomplete/inappropriate epigenetic reprogramming [189, 194, 203, 206-208]. The finding that epigenetic memory of the starting cell is a key determinant of its suitability for reprogramming of the resultant iPS cells to a given cellular lineage [209-214], prompted recent studies to derive iPS cells from primitive bone marrow-derived hematopoietic cells. These studies have confirmed that it is, indeed, far easier/more efficient to generate early hematopoietic cells from iPS cells that were generated by reprogramming primitive bone marrow cells [215]. However, since a major impetus for using iPS technology is that HSC are exceedingly rare in vivo, using these rare hematopoietic cells as the starting population to generate iPS cells seems somewhat circuitous and undermines, to some degree, the advantages of generating HSC from iPS cells. 
Two recent publications $[216,217]$ are the only two studies to-date to report the successful generation of transplantable human HSC from iPS cells. To accomplish this seemingly impossible task, these investigators used a clever trick: they transplanted undifferentiated iPS cells into immunocompromised mice and allowed teratomas to form. Since teratomas contain cells of all three germ layers, they should conceivably contain cells of the hematopoietic lineage. Indeed, both studies showed that HSC were formed within the teratomas, and once isolated, from either the teratoma [216] or from the marrow of teratomabearing mice [217], these HSC repopulated the hematopoietic system of immunodeficient mice, proving their functionality. These studies are of clear importance, since they unequivocally demonstrate that functional HSC can be generated from human iPS cells, thus validating the promise that iPS technology can one day be used to generate patient-specific HSC. However, these studies also highlight the great deal of work that still needs to be done to understand the intrinsic and extrinsic signaling that occurs during hematopoietic development in vivo to efficiently generate functional HSC in vitro via reprogramming technology [189]. Combining these shortcomings with concerns over their long-term safety [196-199], it appears that several key hurdles must be overcome for iPS-derived cells to become clinically viable as a source of HSC for transplantation [194-207, 218].

Two very recent studies, one from the group led by Derrick Rossi and the other from Shahin Rafii's group have taken a major step towards generating clinically viable HSC via reprogramming [219, 220], by showing that it is possible to bypass the need for a pluripotent intermediate step, and simply induce mature cells to adopt the phenotype and functionality of HSC by expressing a carefully selected set of transcription factors. In the study by Rossi and colleagues, the investigators showed that mature murine hematopoietic cells can be coaxed to revert to a more primitive induced-HSC (iHSC) state, and that these iHSC possessed clonal multilineage differentiation potential, were able to reconstitute stem/ progenitor compartments in vivo, and were able to engraft upon serial transplantation. In the other studies, Rafii and colleagues showed that combining the expression of a cocktail of transcription factors with subsequent propagation on a serum-free instructive vascular niche monolayer induces highly purified non-hemogenic human endothelial cells to give rise to hematopoietic colonies containing cells with colony-forming potential and the ability to serially engraft immune-deficient mice. These two studies are highly significant, since bypassing the need for a pluripotent intermediate has eliminated many of the risks inherent to ES cell and iPS cell-based approaches to reprogramming. Indeed, these exciting new findings suggest it may become possible, in the not-to-distant future, to use reprogramming to generate transplantable HSC for the clinic.

\section{HSC Transplantation to Induce Immunological Tolerance and Treat Autoimmunity}

For reasons that are poorly understood, the transplantation and engraftment of even low levels of HSC can render the recipient tolerant to the HSC donor. This phenomenon is now being exploited to combat autoimmune diseases and to reduce/eliminate the immune response to allogeneic solid organ grafts. 
The seminal observation by Owen [221], over 40 years ago, that a high frequency of identical blood types existed in twin pairs of cattle led him to hypothesize that this was the result of exchange of hematopoietic cells between twins in utero. Further ground-breaking studies by Billingham and colleagues [222,223] showed that sustained exposure to foreign antigens during this period produced permanent immune tolerance; thus, Owen's dizygotic twins were rendered immunologically tolerant to one another as a result of this naturallyoccurring hematopoietic cell "transplant" [224-226].

Rodent studies performed by Denman and Morton in the late 1960s/early 1970s [227, 228] revealed that it was possible to transfer an autoimmune disease present in New Zealand Black (NZB) mice to strains of mice that do not normally develop this disease, simply by transplanting hematopoietic cells. Subsequent work proved that the converse was also true, namely that transplanting hematopoietic cells from normal donors could ameliorate autoimmune disease when transferred to affected NZB recipient mice [229], and thus set the stage for evaluating the possibility of using hematopoietic chimerism as a means of inducing donor-specific immune tolerance in organ/tissue transplantation and to restore normal immune balance to correct autoimmune diseases [20, 222, 230, 231].

Unfortunately, although several decades have passed since the first demonstration that hematopoietic chimerism can be used as a means of inducing immune tolerance, the standard of care for organ transplant recipients and for patients with severe autoimmune diseases is still lifelong pharmacologic immunosuppression [232]. A major factor that has precluded the widespread use of HSC transplantation to re-establish tolerance to selfantigens (for autoimmunity) or to induce tolerance to alloantigens present in transplanted solid organs/tissues has been concern regarding the morbidity and mortality associated with allogeneic HSC transplantation, arising from the toxicity associated with the conditioning regimen and from induction of GVHD. As discussed previously, the development of "reduced-intensity transplants" greatly reduced the risks associated with the preconditioning aspects of HSC transplantation, and made it possible to begin performing HSC transplantation in an outpatient setting, and on patients whose old age or medical comorbidities had previously eliminated them as candidates for HSC transplant [233, 234].

\subsection{Autologous HSC Transplant for Autoimmune Disease}

With respect to the risks of GVHD, an unexpected conceptual breakthrough occurred when van Bekkum found that it was possible to cure preclinical animal models of multiple sclerosis (MS) and rheumatoid arthritis (RA) by transplanting autologous HSC [235]. This remarkable discovery suggested it might be possible to treat autoimmune diseases by HSC transplantation without the risk of GVHD. However, subsequent studies revealed that only antigen-induced autoimmune diseases (such as those van Bekkum had employed) could be cured by autologous HSC transplantation; spontaneous autoimmune diseases, which are thought to be polyclonal stem cell diseases [236], cannot. Nevertheless, van Bekkum's unexpected results strengthened the case for using HSC transplantation for autoimmunity, and led to the first clinical autologous HSC transplant for systemic lupus erythematosus (SLE) [237]. 
Given the severe comorbidities present in patients with autoimmunity and those requiring solid organ transplantation, the development of reduced intensity conditioning regimens and the possibility of using autologous HSC in some settings have truly opened the door to the use of HSC transplantation for clinical tolerance induction. Indeed, substantial small and large animal preclinical data [238-259], and a rapidly expanding body of clinical evidence [237, 242, 260-268], have collectively demonstrated that transplantation of autologous or allogeneic HSC can induce tolerance to allogeneic organs/tissues, and reset the host's immune system, leading to elimination of autoreactive $\mathrm{T}$ cells and correction of autoimmunity. This approach has successfully induced tolerance to a diverse range of tissues, including kidney [242, 259, 265, 267-271], heart [245, 268], skin [245, 255], liver [272-275], trachea [251], and vascularized composite tissue allografts (CTA) [255, 257]. It has also successfully reversed autoimmune disorders including SLE [227, 231, 236, 237, 252, 260, 261, 276], Type I diabetes [239, 241, 244, 249, 250, 262], pemphigus vulgaris [276, 277], and experimental allergic encephalomyelitis (a preclinical model for multiple sclerosis) $[235,238,247,248,260,278]$. However, results of clinical trials using HSC transplantation to treat "true" multiple sclerosis have been more mixed; some trials have reported very positive impact on clinical scores and disease progression [278-281], while others have found either no improvement at all, or perhaps even a worsening of neuroinflammation and demyelination following HSC transplant [282, 283].

\subsection{Allogeneic HSC Transplant to Induce Tolerance}

While only some autoimmune diseases can be treated by autologous HSC transplantation, allogeneic HSC transplantation has no such limitations. By virtue of the so-called graftversus-autoimmunity effect, allogeneic HSC transplantation could theoretically promise a cure for any autoimmune disease. Unfortunately, allogeneic HSC transplantation represents a double-edged sword, since with the graft-versus-autoimmunity effect, comes the inherent risk of GVHD, just as occurs with the graft-versus-tumor (GVT) effect, discussed earlier in Section 2. Because transplanting highly enriched/purified HSC grafts can eliminate GVHD, it stands to reason that combining the use of nonmyeloablative preconditioning with enriched/purified HSC grafts should theoretically allow the safe, widespread implementation of allogeneic HSC transplantation for immune tolerance induction. Early murine studies performed by Weissman's group were some of the first to establish that highly purified allogeneic HSC could, like BM grafts, induce immune tolerance to a donor-matched solid organ (heart), while maintaining the ability to reject third-party grafts [284, 285]. These studies also revealed that the timing of the solid organ transplantation relative to the time of HSC infusion was rather flexible, since long-term graft acceptance was achieved regardless of whether the heart and HSC transplantations were performed nearly simultaneously [284] or the HSC were transplanted months before the introduction of a donor-matched heart [285]. Subsequent studies, also by Weissman and colleagues, extended these findings to the realm of autoimmunity, showing that nonmyeloablative conditioning combined with transplantation of highly purified HSC corrected a murine model of SLE [252].

Looking collectively at the preceding studies, it is clear that a standardized, "one-size-fitsall" approach to using HSC transplantation to induce immune tolerance will likely not be possible. Instead, the physician will need to tailor the approach to address the precise aspects 
of the immune system that need to be targeted, based upon the natural pathophysiology of the disease to be treated and the specific mechanisms by which the organ to be transplanted is capable of presenting antigen. While this may seem an insurmountable task, the effort is warranted, given the tremendous impact such an advance would have on the healthcare system and on the quality of life of tens of thousands of patients.

\section{HSC Transplantation for Diseases of Non-Hematopoietic Organs/Tissues}

A great deal of preclinical and clinical evidence over the last 10 years has shown that the transplantation of HSC can also exerts a therapeutic benefit in non-hematopoietic diseases of multiple organs, including the liver, heart, and brain. The mechanism whereby these cells exert their benefit is, however, still an area of intense debate. In this section, we focus on liver disease/failure as a paradigm to illustrate the tremendous potential HSC possess as regenerative medicine therapies, and will then briefly summarize some of the most promising studies that have evaluated the application of HSC to the treatment of diseases/ injuries of other non-hematopoietic tissues, including the heart and brain.

\subsection{HSC Transplantation for Liver Disease}

Given the shortage of available donor organs for transplant, a great deal of time and resources are being devoted to identifying alternatives to organ transplantation to treat liver diseases. Even if a solution to the limited supply of available donor organs could be developed, finding a compatible liver and receiving a transplant is, sadly, just the beginning of a high-risk process that will continue for the remainder of the recipient's life. The transplant itself can fail within the first days post-surgery, requiring the immediate performance of a new transplant. Even if the transplant itself is successful, further intervention may be required to address surgical complications like vessel narrowing, bleeding, or clot formation. Patients are then placed on lifelong immunosuppression, to prevent the life-threatening risk of rejection of the donor liver. This necessitates that these patients are kept under close medical surveillance for the remainder of their lives, since their immunosuppressed state places them at risk of succumbing to infections, and to developing cancers such as leukemias and lymphomas.

Using cell therapy to repopulate/repair the liver would be far less invasive than replacing an entire organ, significantly reducing morbidity and the cost to the patient. Moreover, in some cases, autologous cells could be employed, eliminating the need for costly and dangerous lifelong immunosuppression. Furthermore, a predetermined mixture of cells of specific lineages/differentiative stages could be transplanted to ensure that rapid, perhaps short-term, engraftment would be obtained to quickly supply the patient with the requisite hepatic function. More primitive stem/progenitor cells of the same lineage could also be transplanted, providing, ideally, lifelong correction of the patient. This ability to transplant multiple cells at varying stages of development/differentiation could ultimately circumvent one of the major inherent difficulties with using cellular therapy to treat liver disease, namely, the fact that a certain critical mass of functioning hepatocytes must be present to maintain the basic metabolic requirements for survival [286-289]. Thus, in contrast to HSC transplantation in which the recipient's hematopoietic system can be ablated to create "space" for the infused donor cells to repopulate the system, procedures for replacing the 
mass of the liver through cellular therapy will need to be designed in such a way as to ensure that a certain minimal degree of hepatic function is maintained to keep the patient alive while repopulation with donor cells takes place.

Among the non-hepatic sources of cells that could potentially be used to regenerate/ repopulate the liver, the tissue in the body that has received the greatest amount of attention is the bone marrow. This attention is the result of numerous studies that have provided surprising yet compelling evidence that there are likely several different cell types within the marrow that could be used for liver repair/regeneration. Among these cells types, the one that has been the best studied is the HSC. As discussed in detail in Section 3, HSC can also be isolated from UCB and from $\mathrm{mPB}$, making them readily available in relatively large quantities, and making it possible to harvest them from the patient to be treated using relatively non-invasive procedures.

Over the last several years, HSC have received a great deal of attention in the field of liver regeneration due to pioneering studies by Petersen and colleagues [290] showing that HSC appear to have the unexpected ability to give rise to hepatocyte-like cells in vivo following transplantation in rats, and other studies that quickly followed showing that bone marrowderived cells could completely repopulate the liver of FAH mice [291, 292], correcting their disease phenotype. These initial findings led to a flood of activity in the field using a variety of rodent model systems (genetic lesions or chemical/physical injuries) to rigorously test the hepatocytic potential of HSC from various sources [291, 293-309]. Thus far, results from these studies have been rather hard to interpret, since each group has used slightly different criteria for isolating HSC, and each injury/disease model seems to have its own unique characteristics, resulting in differing outcomes, even when the same or very similar HSC populations are transplanted. However, some general trends that emerge are that human HSC derived from $\mathrm{UCB}$, as opposed to those from bone marrow or $\mathrm{mPB}$, consistently generate significant levels of hepatocytes following transplantation.

Another issue that has become clear is that HSC (like native hepatocytes) engraft at much higher levels when transplanted into recipients whose endogenous hepatocytes are defective as a result of genetic lesion or due to treatment with agents that prevent host hepatocyte replication. In fact, it appears that high levels of donor HSC-derived hepatocytes only occur in these disease/injury models if the transplanted cells possess some sort of proliferative/ survival advantage over the endogenous host cells. However, studies using the fetal sheep model [310-313] have shown that it is possible to take advantage of the inductive microenvironment present within the developing fetal liver, and achieve high levels (up to $20 \%$ ) of donor (human)-derived functional hepatocyte-like cells following the transplantation of highly purified populations of human HSC, in the absence of injury/ disease. Moreover, the use of this model system allowed the investigators to demonstrate that a direct correlation existed between hepatocyte activity and the phenotype of transplanted human HSC, the HSC dose administered, and the source of cells used on a cellper-cell basis (bone marrow, UCB, mPB). Remarkably, the human hepatocyte-like cells generated in this model retained the functional properties of normal hepatocytes, constituted hepatic functional units with the presence of human endothelial and biliary duct cells, and secreted human albumin into the circulation of the recipients. 
Further complicating interpretation of preclinical studies to-date investigating the hepatocytic potential of HSC is the finding that the mechanism whereby the transplanted HSC generate hepatocytes differs depending on the nature of the existing disease/injury. In some cases, such as the FAH model, it appears that the donor-derived hepatocytes are generated almost entirely through the process of cell fusion, in which the transplanted HSC fuse with the host's endogenous hepatocytes, generating cells that morphologically and phenotypically appear to be hepatocytes, yet contain the DNA from both the donor HSC and the host hepatocytes [292, 307, 314]. In other models, including the non-injury fetal sheep model, the hepatocytes appear to be generated almost exclusively through what seems to be true reprogramming/trans-differentiation of the transplanted cells into hepatocytes without exchange of any genetic or cellular elements between the host and the engrafted human cells [293, 297, 306, 308, 315, 316]. Another important caveat is that the phenotype and purity of the cell population transplanted also plays a role in whether hepatocytes are generated and, if so, whether donor-host cell fusion occurs [317-320]. The possible involvement of fusion raises concerns over the clinical use of these cells, since one can imagine that fusion may produce a relatively unstable genome, which, in the presence of existing liver disease/ damage, could potentially induce hepatic tumors.

\subsection{HSC in Clinical Trials for Liver Regeneration}

As a result of these concerns over the risks that may accompany the possibility of cellular fusion and the uncertainty of the outcome, the clinical use of HSC for repair/regeneration within the liver is still in its infancy [321]. Despite these issues, however, the large number of successes seen in animal models has prompted 10 clinical trials using autologous bone marrow-derived cells in patients with liver disease, and 6 clinical trials have used either GCSF-mobilized $\mathrm{mPB}$ or direct G-CSF injections to mobilize endogenous HSC into the circulation in the hopes that they would migrate to the liver and mediate repair/regeneration. The first 6 of the bone marrow-derived trials utilized unsorted bone marrow mononuclear cells [322-327], a population that likely contained both HSC and mesenchymal stromal/ stem cells (MSC), while the remaining 4 used CD34-selected cells [328-331]. Three of the unsorted mononuclear cell trials were, in essence, uncontrolled feasibility studies, in which the number of patients in each case was small and no control arm was included [322, 324, 327]. These trials included patients with a variety of liver diseases/disorder, including hepatitis-associated cirrhosis, alcoholic liver disease, drug-induced acute liver failure, primary sclerosing cholangitis, decompensated cirrhosis, and cryptogenic cirrhosis. The endpoints utilized to assess treatment efficacy included quality of life, aminotransferase levels, model for end-stage liver disease (MELD) scores, and Child-Pugh (CP) score. CP is a clinical metric that is based on measurements of 5 clinical parameters: bilirubin, serum albumin, INR (prothrombin time), the presence/absence of ascites, and the degree of hepatic encephalopathy and its responsiveness to medication. Results of all but one [326] of these studies were promising, with no severe adverse events, and patients exhibiting improvements in one or more of the parameters being measured. Moreover, these benefits were often longterm, lasting several months. The one trial in which no benefit was seen [326] was randomized and controlled, and the authors concluded that the lack of benefit was likely due to this specific disease (decompensated alcoholic cirrhosis) rendering the liver relatively resistant to the regenerative effects of the transplanted cells. 
The four trials to-date employing CD34-selected cells [328-331] were all uncontrolled trials with fewer than 10 patients. Keeping in mind this proviso, these pilot studies reported improvement in serum bilirubin and albumin and CP score following CD34+ cell infusion via hepatic artery or portal vein. Long-term follow-up in one cohort of 5 patients [329] demonstrated that 4 of the 5 patients exhibited improved clinical parameters that persisted for about 1 year post-infusion. The results of this follow-up are very encouraging and argue that the beneficial effects of BM-derived cells on cirrhosis may be fairly prolonged.

However, the benefits in these trials did not come without any risk of adverse events, as one patient died of sepsis, and another developed hepatorenal syndrome, leading to discontinuation of one particular trial [331]. Similarly, in study by Mohamadnejad and colleagues [330], the infusion of CD34+ cells via the hepatic artery was deemed to be unsafe and ineffective, since one patient died as a result of liver failure secondary to type 1 hepatorenal syndrome, and only 1 of the remaining 3 patients showed evidence of marginal improvement in clinical parameters.

As was the case with the studies using bone marrow-derived HSC, two-thirds of studies todate using G-CSF mobilized HSC or G-CSF injection to treat liver disease have also been small patient number, uncontrolled pilots [332-337]. Further complicating data analysis and comparison between these trials, some studies utilized autologous HSC derived from G-CSF $\mathrm{mPB}$, some administered G-CSF directly to mobilize the patient's endogenous HSC, and some trials combined these approaches by injecting G-CSF and administering mPB-derived HSC. Despite these issues, these trials have shown that the use of G-CSF or G-CSF mPB appears to be safe and well tolerated, and G-CSF mobilization also appears to exert a significant therapeutic effect, as all 6 trials reported significant improvements in CP scores and MELD scores, improved survival rates, and improved sequential organ failure assessment (SOFA) scores, with some trials following patients for over 1 year after treatment.

Collectively, these studies with unselected or CD34-selected cells and with G-CSF mobilized mPB-derived cells provide hope that HSC may prove to be a valuable resource for cell-based therapies for liver disease. However, the results of these studies must be interpreted with some trepidation, given the limited number of patients enrolled in each trial, the frequent lack of appropriate controls, and the occurrence of adverse events in at least two of these trials. Furthermore, since the cells in all of these trials were autologously derived, there was no way for the investigators to assess the actual engraftment, persistence, or differentiative potential of the transplanted cells, leaving one to speculate as to the mechanism responsible for the observed clinical improvements.

\subsection{HSC Transplantation for Diseases/Injuries of other Tissues}

As many metabolic disorders affect the developing central nervous system (CNS), and there are currently no therapies that can promise correction following brain/spinal injuries, the finding that HSC transplantation could improve liver function following disease/injury led investigators to study the ability of marrow-derived cells to contribute to repair/regeneration within the CNS. Early studies by Eglitis \& Mezey [338] set the stage by clearly demonstrating that marrow cells were able to differentiate into both microglia and astroglia 
within the brains of murine BMT recipients. The ability of marrow-derived cells to give rise to astroglia was quite surprising, as astroglia are derived from the neuroectoderm, and should thus be developmentally distinct from the marrow. Two subsequent studies [339, 340] extended these initial findings by showing that intravenously infused marrow cells migrated to the brains of adult mice and differentiated into large numbers of cells expressing neuronal markers. While subsequent in vitro studies provided contradictory evidence that enriched populations of murine marrow-derived HSC do not, in fact, possess the ability to form functional neuronal cells capable of firing an action potential [341], the finding that mesoderm-derived marrow cells possess the ability to adopt neural cell fates in vivo, prompted further preclinical investigation and, eventually, clinical trials in patients with stroke/ischemic brain injury [342-347]. In similarity to the clinical trials presented above for liver disease, the clinical trials thus far for stroke have utilized multiple cell populations from different sources, and some have included G-CSF treatment to mobilize the patient's endogenous HSC. These studies have shown that G-CSF and HSC can safely be administered to patients with stroke, and that prior labeling of the HSC with either iron microbeads or 99-Technetium allows the in vivo tracking of these cells for at least 24 hours post-infusion. Semi-selective accumulation of HSC at the site of injury and a trend towards a reduction in MRI ischemic lesion volume were also observed in one trial [348], but there are too few trials/patients to conclude with certainty the degree of improvement HSC mediate in this clinical setting, nor the mechanism that is responsible for any observed benefit. In similarity to the prior section detailing the use of HSC to repair/regenerate the liver, preclinical animal studies utilizing HSC from umbilical cord blood have shown that these cells also have the ability to migrate with some degree of selectivity to sites of injury/ damage within the brain, and mediate repair following ischemic injury [349-355]. However, clinical trials have not yet been undertaken to assess the benefit cord blood-derived HSC will produce in human patients with ischemic injury/stroke.

Myocardial infarction (MI) is another major clinical target for which bone marrow cells are being explored to induce repair/regeneration. A large number of preclinical studies have been performed to test the ability of bone marrow and UCB-derived cells to repair the injured myocardium following MI [356-372], which were all set into motion by the pioneering studies conducted almost 15 years ago by Don Orlic [373-375]. These preclinical studies have led to an array of clinical trials using either HSC or G-CSF treatment to mobilize HSC to the infarct site [376-397]. Indeed, MI is probably the clinical setting in which HSC, and other bone marrow-derived populations, have been the most extensively studied, likely due in no small part to the fact that heart disease is one of the leading causes of death worldwide. With one exception [384], these preclinical and clinical studies have collectively provided compelling evidence that infusing HSC, or administering G-CSF to mobilize the patient's endogenous HSC, can each lead to a reduction in infarct size, reduced left ventricular remodeling, and long-lasting functional improvement. In the one study that made a direct comparison [380], combining G-CSF injections with an infusion of mPB cells was found to be even more effective than administering G-CSF alone. One interesting finding that has also emerged is that the levels of engraftment are too low to support the conclusion that the marked beneficial effects on cardiac function is due to reprogramming/ trans-differentiation of the transplanted cells to generate new cardiomyocytes. Rather, it 
seems that the infused cells are likely mediating their effects by: 1) dampening existent inflammation; 2) stimulating angiogenesis to restore blood flow to the infarcted zone; 3 ) restoring balance to the pro-apoptotic cytokine milieu of the damaged myocardium; and 4) releasing paracrine factors to promote repair and/or activate endogenous cardiac stem/ progenitor cell populations. However, just as was the case with the previously discussed clinical trials in liver and stroke, the interpretation of the clinical data to-date in these trials for MI is not particularly straightforward. The main issue contributing to this lack of clarity is the use of somewhat poorly defined cell populations in many of these studies. G-CSF was originally developed and used to mobilize HSC, but it has now been shown that G-CSF can also mobilize MSC and EPC [391], populations that can exert their own trophic/paracrine and pro-angiogenic effects, respectively. Similarly, although the CD34 antigen has traditionally been used to isolate $\mathrm{HSC}$, it is also present on endothelial progenitor cells (EPC) [398]. As such, selecting CD34+ cells from G-CSF mPB likely yields a population enriched for both HSC and EPC. Nonetheless, future studies can likely resolve the issue of whether the observed effects are due solely to the HSC, and the trials to-date leave no doubt that bone marrow-derived cells can exert a pronounced therapeutic benefit following MI.

\section{Summary/Conclusions}

HSC represent the quintessential stem cell [399], and are likely the most studied and best understood stem cell within the body. Since their discovery/identification, HSC have been the focus of intensive research, and have proven to be invaluable and life saving following inadvertent radiation exposure and in the treatment of hematologic malignancies. In addition to the bone marrow, HSC can also be isolated from umbilical cord blood and from cytokinemobilized peripheral blood, making them readily available in relatively large quantities, and making relatively non-invasive collection possible. The ability of HSC to completely repopulate the entire hematopoietic system would already guarantee them a valuable place in regenerative medicine, but the finding that hematopoietic chimerism can induce immune tolerance to solid organs and correct autoimmune diseases such as SLE, multiple sclerosis, and diabetes further broadened HSC's clinical utility. This utility has increased yet again in recent years, with the demonstration that these cells, through a variety of mechanisms, promote repair/regeneration of tissues as diverse as liver, heart, and brain (and others that were not discussed, due to space constraints). By reviewing the existing literature on preclinical studies in small and large animals, and comparing/contrasting the results obtained in these models to the outcome in human clinical trials to-date, it is clear that mice are absolutely essential and invaluable tools for understanding basic HSC biology and for developing novel therapeutic approaches to treat human disease. However, these collective data also highlight the critical point that, despite their great value, mice are not simply "little humans", and promising results obtained in murine models do not always translate directly into therapeutic success in the clinical arena. As such, it is essential to identify and make use of an animal model system that most closely approximates the specific human physiological and/or disease processes when performing preclinical safety and efficacy studies.

In conclusion, it is hoped that this review has provided the reader with a glimpse into the remarkable potential HSC possess, and highlighted their value as therapeutics in regenerative medicine. 


\section{Acknowledgments}

Supported by Grants R01-HL097623 and R21-HL117704 from National Institutes of Health (NIH), and Grant NNX13AB67G from National Aeronautics and Space Administration (NASA)

\section{References}

1. Ng YY, Baert MR, de Haas EF, Pike-Overzet K, Staal FJ. Isolation of human and mouse hematopoietic stem cells. Methods Mol Biol. 2009; 506:13-21. [PubMed: 19110616]

2. Taichman RS. Blood and bone: two tissues whose fates are intertwined to create the hematopoietic stem-cell niche. Blood. 2005; 105(7):2631-9. [PubMed: 15585658]

3. Wilson A, Trumpp A. Bone-marrow haematopoietic-stem-cell niches. Nat Rev Immunol. 2006; 6(2):93-106. [PubMed: 16491134]

4. Papayannopoulou T, Scadden DT. Stem-cell ecology and stem cells in motion. Blood. 2008; 111(8): 3923-30. [PubMed: 18398055]

5. Xie Y, Yin T, Wiegraebe W, He XC, Miller D, Stark D, Perko K, Alexander R, Schwartz J, Grindley JC, Park J, Haug JS, Wunderlich JP, Li H, Zhang S, Johnson T, Feldman RA, Li L. Detection of functional haematopoietic stem cell niche using real-time imaging. Nature. 2009; 457(7225):97101. [PubMed: 19052548]

6. Morrison SJ, Scadden DT. The bone marrow niche for haematopoietic stem cells. Nature. 2014; 505(7483):327-34. [PubMed: 24429631]

7. Anthony BA, Link DC. Regulation of hematopoietic stem cells by bone marrow stromal cells. Trends Immunol. 2014; 35(1):32-7. [PubMed: 24210164]

8. Ding L, Saunders TL, Enikolopov G, Morrison SJ. Endothelial and perivascular cells maintain haematopoietic stem cells. Nature. 2012; 481(7382):457-62. [PubMed: 22281595]

9. Levesque JP I, Winkler G. Hierarchy of immature hematopoietic cells related to blood flow and niche. Curr Opin Hematol. 2011; 18(4):220-5. [PubMed: 21519242]

10. Mendez-Ferrer S, Michurina TV, Ferraro F, Mazloom AR, Macarthur BD, Lira SA, Scadden DT, Ma'ayan A, Enikolopov GN, Frenette PS. Mesenchymal and haematopoietic stem cells form a unique bone marrow niche. Nature. 2010; 466(7308):829-34. [PubMed: 20703299]

11. Sabin FR, Doan CA, Forkner CE. The Production of Osteogenic Sarcomata and the Effects on Lymph Nodes and Bone Marrow of Intravenous Injections of Radium Chloride and Mesothorium in Rabbits. J Exp Med. 1932; 56(2):267-89. [PubMed: 19870065]

12. Sabin FR, Miller FR, Smithburn KC, Thomas RM, Hummel LE. Changes in the Bone Marrow and Blood Cells of Developing Rabbits. J Exp Med. 1936; 64(1):97-120. [PubMed: 19870526]

13. Thomas ED, Lochte HL Jr, Lu WC, Ferrebee JW. Intravenous infusion of bone marrow in patients receiving radiation and chemotherapy. N Engl J Med. 1957; 257(11):491-6. [PubMed: 13464965]

14. Till JE, McCulloch EA. A direct measurement of the radiation sensitivity of normal mouse bone marrow cells. Radiat Res. 1961; 14:213-22. [PubMed: 13776896]

15. Becker AJ, McCulloch EA, Till JE. Cytological demonstration of the clonal nature of spleen colonies derived from transplanted mouse marrow cells. Nature. 1963; 197:452-4. [PubMed: 13970094]

16. Jacobson LO, Marks EK, Robson MJ, Gaston EO, Zirkle RE. Effect of spleen protection on mortality following x-irradiation. J Lab Clin Med. 1949; 34:1538-1543.

17. Lorenz E, Uphoff D, Reid TR, Shelton E. Modification of irradiation injury in mice and guinea pigs by bone marrow injections. J Natl Cancer Inst. 1951; 12(1):197-201. [PubMed: 14874130]

18. Barnes DWH, Loutit JF. What is the recovery factor in spleen? Nucleonics. 1954; 12:68-71.

19. Ford CE, Hamerton JL, Barnes DW, Loutit JF. Cytological identification of radiation-chimaeras. Nature. 1956; 177(4506):452-4. [PubMed: 13309336]

20. Main JM, Prehn RT. Successful skin homografts after the administration of high dosage X radiation and homologous bone marrow. J Natl Cancer Inst. 1955; 15(4):1023-9. [PubMed: 13233946] 
21. Nowell PC, Cole LJ, Habermeyer JG, Roan PL. Growth and continued function of rat marrow cells in X-radiated mice. Cancer Res. 1956; 16(3):258-61. [PubMed: 13304871]

22. Trentin JJ. Mortality and skin transplantability in $\mathrm{x}$-irradiated mice receiving isologous, homologous or heterologous bone marrow. Proc Soc Exp Biol Med. 1956; 92(4):688-93. [PubMed: 13370496]

23. Little MT, Storb R. History of haematopoietic stem-cell transplantation. Nat Rev Cancer. 2002; 2(3):231-8. [PubMed: 11990860]

24. Thomas ED, Lochte HL Jr, Cannon JH, Sahler OD, Ferrebee JW. Supralethal whole body irradiation and isologous marrow transplantation in man. J Clin Invest. 1959; 38:1709-16. [PubMed: 13837954]

25. Mathe G, Amiel JL, Schwarzenberg L, Cattan A, Schneider M. Adoptive immunotherapy of acute leukemia: experimental and clinical results. Cancer Res. 1965; 25(9):1525-31. [PubMed: 5323965]

26. Andrews GA. Criticality accidents in Vinca, Yugoslavia, and Oak Ridge, Tennessee. Comparison of radiation injuries and results of therapy. JAMA. 1962; 179:191-7. [PubMed: 13861486]

27. McLaughlin, TP.; Monahan, SP.; Pruvost, NL.; frolov, VV.; Ryazanov, BG.; Sviridov, VL. A Review of Criticality Accidents. Vol. LA-13638. Los Alamos: Los Alamos National Laboratory; 2000. 2000 Revision ed

28. McGovern JJ Jr, Russell PS, Atkins L, Webster EW. Treatment of terminal leukemic relapse by total-body irradiation and intravenous infusion of stored autologous bone marrow obtained during remission. N Engl J Med. 1959; 260(14):675-83. [PubMed: 13644566]

29. Thomas ED, Storb R, Clift RA, Fefer A, Johnson L, Neiman PE, Lerner KG, Glucksberg H, Buckner CD. Bone-marrow transplantation (second of two parts). N Engl J Med. 1975; 292(17): 895-902. [PubMed: 235092]

30. van Bekkum, DW.; de Vries, MJ.; Rijswijk, ZH., editors. Radiation Chimaeras. Logos Press Limited; London: 1967.

31. Barriga F, Ramirez P, Wietstruck A, Rojas N. Hematopoietic stem cell transplantation: clinical use and perspectives. Biol Res. 2012; 45(3):307-16. [PubMed: 23283440]

32. Patel SA, Rameshwar P. Stem Cell Transplantation for Hematological Malignancies: Prospects for Personalized Medicine and Co-therapy with Mesenchymal Stem Cells. Curr Pharmacogenomics Person Med. 2011; 9(3):229-239. [PubMed: 21892378]

33. Epstein RB, Storb R, Ragde H, Thomas ED. Cytotoxic typing antisera for marrow grafting in littermate dogs. Transplantation. 1968; 6(1):45-58. [PubMed: 4866738]

34. Storb R, Epstein RB, Bryant J, Ragde H, Thomas ED. Marrow grafts by combined marrow and leukocyte infusions in unrelated dogs selected by histocompatibility typing. Transplantation. 1968; 6(4):587-93. [PubMed: 4876499]

35. Storb R, Rudolph RH, Thomas ED. Marrow grafts between canine siblings matched by serotyping and mixed leukocyte culture. J Clin Invest. 1971; 50(6):1272-5. [PubMed: 4931083]

36. Bodenberger U, Kolb HJ, Rieder I, Netzel B, Schaffer E, Kolb H, Thierfelder S. Fractionated total body irradiation and autologous bone marrow transplantation in dogs: hemopoietic recovery after various marrow cell doses. Exp Hematol. 1980; 8(4):384-94. [PubMed: 7007066]

37. Cavins JA, Kasakura S, Thomas ED, Ferrebee JW. Recovery of lethally irradiated dogs following infusion of autologous marrow stored at low temperature in dimethylsulphoxide. Blood. 1962; 20:730-4. [PubMed: 14019494]

38. Cavins JA, Scheer SC, Thomas ED, Ferrebee JW. The Recovery of Lethally Irradiated Dogs Given Infusions of Autologous Leukocytes Preserved at -80 C. Blood. 1964; 23:38-42. [PubMed: 14113471]

39. Deeg HJ, Storb R, Longton G, Graham TC, Shulman HM, Appelbaum F, Thomas ED. Single dose or fractionated total body irradiation and autologous marrow transplantation in dogs: effects of exposure rate, fraction size, and fractionation interval on acute and delayed toxicity. Int J Radiat Oncol Biol Phys. 1988; 15(3):647-53. [PubMed: 3047091]

40. Mannick JA, Lochte HL Jr, Ashley CA, Thomas ED, Ferrebee JW. Autografts of bone marrow in dogs after lethal total-body radiation. Blood. 1960; 15:255-66. [PubMed: 14420699] 
41. Storb R, Deeg HJ. Failure of allogeneic canine marrow grafts after total-body irradiation. Allogeneic "resistance" versus transfusion-induced sensitization. Transplantation. 1986; 42(6): 571-80. [PubMed: 3538545]

42. Storb R, Raff RF, Appelbaum FR, Deeg HJ, Graham TC, Schuening FG, Sale G, Bryant E, Seidel $\mathrm{K}$. Fractionated versus single-dose total body irradiation at low and high dose rates to condition canine littermates for DLA-identical marrow grafts. Blood. 1994; 83(11):3384-9. [PubMed: 8193376]

43. Storb R, Raff RF, Appelbaum FR, Schuening FW, Sandmaier BM, Graham TC, Thomas ED. What radiation dose for DLA-identical canine marrow grafts? Blood. 1988; 72(4):1300-4. [PubMed: 3048439]

44. Storb R, Rudolph RH, Kolb HJ, Graham TC, Mickelson E, Erickson V, Lerner KG, Kolb H, Thomas ED. Marrow grafts between DL-A-matched canine littermates. Transplantation. 1973; 15(1):92-100. [PubMed: 4268054]

45. Thomas ED, LeBlond R, Graham T, Storb R. Marrow infusions in dogs given midlethal or lethal irradiation. Radiat Res. 1970; 41(1):113-24. [PubMed: 4902537]

46. Korbling M, Fliedner TM, Calvo W, Ross WM, Nothdurft W, Steinbach I. Albumin density gradient purification of canine hemopoietic blood stem cells (HBSC): long-term allogeneic engraftment without GVH-reaction. Exp Hematol. 1979; 7(6):277-88. [PubMed: 39771]

47. Storb R, Epstein RB, Ragde H, Bryant J, Thomas ED. Marrow engraftment by allogeneic leukocytes in lethally irradiated dogs. Blood. 1967; 30(6):805-11. [PubMed: 4865037]

48. Snell GD. The Nobel Lectures in Immunology. Lecture for the Nobel Prize for Physiology or Medicine, 1980: Studies in histocompatibility. Scand J Immunol. 1992; 36(4):513-26. [PubMed: 1411297]

49. Epstein RB, Storb R, Clift RA, Thomas ED. Autologous bone marrow grafts in dogs treated with lethal doses of cyclophosphamide. Cancer Res. 1969; 29(5):1072-5. [PubMed: 4889109]

50. Santos GW, Owens AH Jr. Allogeneic marrow transplants in cyclophosphamide treated mice. Transplant Proc. 1969; 1(1):44-6. [PubMed: 4400067]

51. Santos GW, Sensenbrenner LL, Burke PJ, Colvin M, Owens AH Jr, Bias WB, Slavin RE. Marrow transplanation in man following cyclophosphamide. Transplant Proc. 1971; 3(1):400-4. [PubMed: 4398496]

52. Storb R, Buckner CD, Dillingham LA, Thomas ED. Cyclophosphamide regimens in rhesus monkey with and without marrow infusion. Cancer Res. 1970; 30(8):2195-203. [PubMed: 4990004]

53. Storb R, Epstein RB, Rudolph RH, Thomas ED. Allogeneic canine bone marrow transplantation following cyclophosphamide. Transplantation. 1969; 7(5):378-86. [PubMed: 4890905]

54. Thomas ED, Buckner CD, Rudolph RH, Fefer A, Storb R, Neiman PE, Bryant JI, Chard RL, Clift RA, Epstein RB, Fialkow PJ, Funk DD, Giblett ER, Lerner KG, Reynolds FA, Slichter S. Allogeneic marrow grafting for hematologic malignancy using HL-A matched donor-recipient sibling pairs. Blood. 1971; 38(3):267-87. [PubMed: 4399859]

55. Deeg HJ, Storb R, Appelbaum FR, Kennedy MS, Graham TC, Thomas ED. Combined immunosuppression with cyclosporine and methotrexate in dogs given bone marrow grafts from DLA-haploidentical littermates. Transplantation. 1984; 37(1):62-5. [PubMed: 6364490]

56. Deeg HJ, Storb R, Weiden PL, Raff RF, Sale GE, Atkinson K, Graham TC, Thomas ED. Cyclosporin A and methotrexate in canine marrow transplantation: engraftment, graft-versus-host disease, and induction of intolerance. Transplantation. 1982; 34(1):30-5. [PubMed: 6750877]

57. Lochte HL Jr, Levy AS, Guenther DM, Thomas ED, Ferrebee JW. Prevention of delayed foreign marrow reaction in lethally irradiated mice by early administration of methotrexate. Nature. 1962; 196:1110-1. [PubMed: 13931175]

58. Storb R, Epstein RB, Graham TC, Thomas ED. Methotrexate regimens for control of graft-versushost disease in dogs with allogeneic marrow grafts. Transplantation. 1970; 9(3):240-6. [PubMed: 4392379]

59. Storb R, Raff RF, Appelbaum FR, Deeg HJ, Fitzsimmons W, Graham TC, Pepe M, Pettinger M, Sale G, van der Jagt R, et al. FK-506 and methotrexate prevent graft-versus-host disease in dogs 
given 9.2 Gy total body irradiation and marrow grafts from unrelated dog leukocyte antigennonidentical donors. Transplantation. 1993; 56(4):800-7. [PubMed: 7692635]

60. Storb R, Thomas ED. Graft-versus-host disease in dog and man: the Seattle experience. Immunol Rev. 1985; 88:215-38. [PubMed: 3910558]

61. Thomas ED, Collins JA, Herman EC Jr, Ferrebee JW. Marrow transplants in lethally irradiated dogs given methotrexate. Blood. 1962; 19:217-28. [PubMed: 13920766]

62. Uphoff DE. Alteration of homograft reaction by A-methopterin in lethally irradiated mice treated with homologous marrow. Proc Soc Exp Biol Med. 1958; 99(3):651-3. [PubMed: 13614453]

63. Atkinson K, Storb R, Weiden PL, Deeg HJ, Gerhard-Miller L, Thomas ED. In vitro tests correlating with presence or absence of graft-vs-host disease in DLA nonidentical canine radiation chimeras: evidence that clonal abortion maintains stable graft-host tolerance. J Immunol. 1980; 124(4):1808-14. [PubMed: 6154081]

64. Deeg HJ, Atkinson K, Weiden PW, Storb R. Mechanisms of tolerance in canine radiation chimeras. Transplant Proc. 1987; 19(6 Suppl 7):75-81. [PubMed: 2962356]

65. Tsoi MS, Storb R, Weiden PL, Graham TC, Schroeder ML, Thomas ED. Canine marrow transplantation: are serum blocking factors necessary to maintain the stable chimeric state? $\mathrm{J}$ Immunol. 1975; 114(2 Pt 1):531-9. [PubMed: 1091699]

66. Weiden PL, Storb R, Tsoi MS, Graham TC, Lerner KG, Thomas ED. Infusion of donor lymphocytes into stable canine radiation chimeras: implications for mechanism of transplantation tolerance. J Immunol. 1976; 116(5):1212-9. [PubMed: 774975]

67. Choi SW, Levine JE, Ferrara JL. Pathogenesis and management of graft-versus-host disease. Immunol Allergy Clin North Am. 2010; 30(1):75-101. [PubMed: 20113888]

68. Ratanatharathorn V, Nash RA, Przepiorka D, Devine SM, Klein JL, Weisdorf D, Fay JW, Nademanee A, Antin JH, Christiansen NP, van der Jagt R, Herzig RH, Litzow MR, Wolff SN, Longo WL, Petersen FB, Karanes C, Avalos B, Storb R, Buell DN, Maher RM, Fitzsimmons WE, Wingard JR. Phase III study comparing methotrexate and tacrolimus (prograf, FK506) with methotrexate and cyclosporine for graft-versus-host disease prophylaxis after HLA-identical sibling bone marrow transplantation. Blood. 1998; 92(7):2303-14. [PubMed: 9746768]

69. Storb R, Deeg HJ, Whitehead J, Appelbaum F, Beatty P, Bensinger W, Buckner CD, Clift R, Doney $\mathrm{K}$, Farewell V, et al. Methotrexate and cyclosporine compared with cyclosporine alone for prophylaxis of acute graft versus host disease after marrow transplantation for leukemia. N Engl J Med. 1986; 314(12):729-35. [PubMed: 3513012]

70. Storb R, Prentice RL, Thomas ED. Treatment of aplastic anemia by marrow transplantation from HLA identical siblings. Prognostic factors associated with graft versus host disease and survival. J Clin Invest. 1977; 59(4):625-32. [PubMed: 14972]

71. Prentice HG, Blacklock HA, Janossy G, Gilmore MJ, Price-Jones L, Tidman N, Trejdosiewicz LK, Skeggs DB, Panjwani D, Ball S, et al. Depletion of T lymphocytes in donor marrow prevents significant graft-versus-host disease in matched allogeneic leukaemic marrow transplant recipients. Lancet. 1984; 1(8375):472-6. [PubMed: 6142207]

72. Reisner Y, Kapoor N, Kirkpatrick D, Pollack MS, Dupont B, Good RA, O’Reilly RJ. Transplantation for acute leukaemia with HLA-A and B nonidentical parental marrow cells fractionated with soybean agglutinin and sheep red blood cells. Lancet. 1981; 2(8242):327-31. [PubMed: 6115110]

73. Negrin RS, Atkinson K, Leemhuis T, Hanania E, Juttner C, Tierney K, Hu WW, Johnston LJ, Shizurn JA, Stockerl-Goldstein KE, Blume KG, Weissman IL, Bower S, Baynes R, Dansey R, Karanes C, Peters W, Klein J. Transplantation of highly purified CD34+Thy-1+ hematopoietic stem cells in patients with metastatic breast cancer. Biol Blood Marrow Transplant. 2000; 6(3): 262-71. [PubMed: 10871151]

74. Vose JM, Bierman PJ, Lynch JC, Atkinson K, Juttner C, Hanania CE, Bociek G, Armitage JO. Transplantation of highly purified CD34+Thy-1+ hematopoietic stem cells in patients with recurrent indolent non-Hodgkin's lymphoma. Biol Blood Marrow Transplant. 2001; 7(12):680-7. [PubMed: 11787531]

75. Michallet M, Philip T, Philip I, Godinot H, Sebban C, Salles G, Thiebaut A, Biron P, Lopez F, Mazars P, Roubi N, Leemhuis T, Hanania E, Reading C, Fine G, Atkinson K, Juttner C, Coiffier B, 
Fiere D, Archimbaud E. Transplantation with selected autologous peripheral blood CD34+Thy1+ hematopoietic stem cells (HSCs) in multiple myeloma: impact of HSC dose on engraftment, safety, and immune reconstitution. Exp Hematol. 2000; 28(7):858-70. [PubMed: 10907648]

76. Gazitt Y, Reading CC, Hoffman R, Wickrema A, Vesole DH, Jagannath S, Condino J, Lee B, Barlogie B, Tricot G. Purified CD34+ Lin- Thy+ stem cells do not contain clonal myeloma cells. Blood. 1995; 86(1):381-9. [PubMed: 7540887]

77. Shizuru JA, Negrin RS, Weissman IL. Hematopoietic stem and progenitor cells: clinical and preclinical regeneration of the hematolymphoid system. Annu Rev Med. 2005; 56:509-38. [PubMed: 15660525]

78. Goldman JM, Baughan AS, McCarthy DM, Worsley AM, Hows JM, Gordon-Smith EC, Catovsky D, Batchelor JR, Goolden AW, Galton DA. Marrow transplantation for patients in the chronic phase of chronic granulocytic leukaemia. Lancet. 1982; 2(8299):623-5. [PubMed: 6125773]

79. Goldman JM, Gale RP, Horowitz MM, Biggs JC, Champlin RE, Gluckman E, Hoffmann RG, Jacobsen SJ, Marmont AM, McGlave PB, et al. Bone marrow transplantation for chronic myelogenous leukemia in chronic phase. Increased risk for relapse associated with T-cell depletion. Ann Intern Med. 1988; 108(6):806-14. [PubMed: 3285744]

80. Marmont AM, Horowitz MM, Gale RP, Sobocinski K, Ash RC, van Bekkum DW, Champlin RE, Dicke KA, Goldman JM, Good RA, et al. T-cell depletion of HLA-identical transplants in leukemia. Blood. 1991; 78(8):2120-30. [PubMed: 1912589]

81. Martin PJ, Hansen JA, Buckner CD, Sanders JE, Deeg HJ, Stewart P, Appelbaum FR, Clift R, Fefer A, Witherspoon RP, et al. Effects of in vitro depletion of T cells in HLA-identical allogeneic marrow grafts. Blood. 1985; 66(3):664-72. [PubMed: 3896348]

82. Goodrich JM, Mori M, Gleaves CA, Du Mond C, Cays M, Ebeling DF, Buhles WC, DeArmond B, Meyers JD. Early treatment with ganciclovir to prevent cytomegalovirus disease after allogeneic bone marrow transplantation. N Engl J Med. 1991; 325(23):1601-7. [PubMed: 1658652]

83. Schmidt GM, Horak DA, Niland JC, Duncan SR, Forman SJ, Zaia JA. A randomized, controlled trial of prophylactic ganciclovir for cytomegalovirus pulmonary infection in recipients of allogeneic bone marrow transplants; The City of Hope-Stanford-Syntex CMV Study Group. N Engl J Med. 1991; 324(15):1005-11. [PubMed: 1848679]

84. Tomblyn M, Chiller T, Einsele H, Gress R, Sepkowitz K, Storek J, Wingard JR, Young JA, Boeckh MJ. Guidelines for preventing infectious complications among hematopoietic cell transplantation recipients: a global perspective. Biol Blood Marrow Transplant. 2009; 15(10):1143-238. [PubMed: 19747629]

85. Barnes DW, Corp MJ, Loutit JF, Neal FE. Treatment of murine leukaemia with X rays and homologous bone marrow; preliminary communication. Br Med J. 1956; 2(4993):626-7. [PubMed: 13356034]

86. Barnes DW, Loutit JF. Treatment of murine leukaemia with x-rays and homologous bone marrow. II. Br J Haematol. 1957; 3(3):241-52. [PubMed: 13460193]

87. Sullivan KM, Weiden PL, Storb R, Witherspoon RP, Fefer A, Fisher L, Buckner CD, Anasetti C, Appelbaum FR, Badger C, et al. Influence of acute and chronic graft-versus-host disease on relapse and survival after bone marrow transplantation from HLA-identical siblings as treatment of acute and chronic leukemia. Blood. 1989; 73(6):1720-8. [PubMed: 2653460]

88. Weiden PL, Flournoy N, Thomas ED, Prentice R, Fefer A, Buckner CD, Storb R. Antileukemic effect of graft-versus-host disease in human recipients of allogeneic-marrow grafts. N Engl J Med. 1979; 300(19):1068-73. [PubMed: 34792]

89. Weiden PL, Sullivan KM, Flournoy N, Storb R, Thomas ED. Antileukemic effect of chronic graftversus-host disease: contribution to improved survival after allogeneic marrow transplantation. $\mathrm{N}$ Engl J Med. 1981; 304(25):1529-33. [PubMed: 7015133]

90. Aversa F, Tabilio A, Velardi A, Cunningham I, Terenzi A, Falzetti F, Ruggeri L, Barbabietola G, Aristei C, Latini P, Reisner Y, Martelli MF. Treatment of high-risk acute leukemia with T-celldepleted stem cells from related donors with one fully mismatched HLA haplotype. N Engl J Med. 1998; 339(17):1186-93. [PubMed: 9780338]

91. Aversa F, Terenzi A, Carotti A, Felicini R, Jacucci R, Zei T, Latini P, Aristei C, Santucci A, Martelli MP, Cunningham I, Reisner Y, Martelli MF. Improved outcome with T-cell-depleted bone 
marrow transplantation for acute leukemia. J Clin Oncol. 1999; 17(5):1545-50. [PubMed: 10334542]

92. Papadopoulos EB, Carabasi MH, Castro-Malaspina H, Childs BH, Mackinnon S, Boulad F, Gillio AP, Kernan NA, Small TN, Szabolcs P, Taylor J, Yahalom J, Collins NH, Bleau SA, Black PM, Heller G, O'Reilly RJ, Young JW. T-cell-depleted allogeneic bone marrow transplantation as postremission therapy for acute myelogenous leukemia: freedom from relapse in the absence of graft-versus-host disease. Blood. 1998; 91(3):1083-90. [PubMed: 9446672]

93. Storb R, Weiden PL, Graham TC, Lerner KG, Thomas ED. Marrow grafts between unrelated dogs homozygous and identical for DLA antigens. Transplant Proc. 1977; 9(1):281-3. [PubMed: 17195]

94. Horowitz MM, Gale RP, Sondel PM, Goldman JM, Kersey J, Kolb HJ, Rimm AA, Ringden O, Rozman C, Speck B, et al. Graft-versus-leukemia reactions after bone marrow transplantation. Blood. 1990; 75(3):555-62. [PubMed: 2297567]

95. Martin PJ, Hansen JA, Torok-Storb B, Durnam D, Przepiorka D, O'Quigley J, Sanders J, Sullivan KM, Witherspoon RP, Deeg HJ, et al. Graft failure in patients receiving T cell-depleted HLAidentical allogeneic marrow transplants. Bone Marrow Transplant. 1988; 3(5):445-56. [PubMed: 3056552]

96. Kolb HJ, Mittermuller J, Clemm C, Holler E, Ledderose G, Brehm G, Heim M, Wilmanns W. Donor leukocyte transfusions for treatment of recurrent chronic myelogenous leukemia in marrow transplant patients. Blood. 1990; 76(12):2462-5. [PubMed: 2265242]

97. Feinstein L, Sandmaier B, Maloney D, McSweeney PA, Maris M, Flowers C, Radich J, Little MT, Nash RA, Chauncey T, Woolfrey A, Georges G, Kiem HP, Zaucha JM, Blume KG, Shizuru J, Niederwieser D, Storb R. Nonmyeloablative hematopoietic cell transplantation. Replacing highdose cytotoxic therapy by the graft-versus-tumor effect. Ann N Y Acad Sci. 2001; 938:328-37. discussion 337-9. [PubMed: 11458521]

98. Giralt S, Estey E, Albitar M, van Besien K, Rondon G, Anderlini P, O’Brien S, Khouri I, Gajewski J, Mehra R, Claxton D, Andersson B, Beran M, Przepiorka D, Koller C, Kornblau S, Korbling M, Keating M, Kantarjian H, Champlin R. Engraftment of allogeneic hematopoietic progenitor cells with purine analog-containing chemotherapy: harnessing graft-versus-leukemia without myeloablative therapy. Blood. 1997; 89(12):4531-6. [PubMed: 9192777]

99. Khouri IF, Keating M, Korbling M, Przepiorka D, Anderlini P, O’Brien S, Giralt S, Ippoliti C, von Wolff B, Gajewski J, Donato M, Claxton D, Ueno N, Andersson B, Gee A, Champlin R. Transplant-lite: induction of graft-versus-malignancy using fludarabine-based nonablative chemotherapy and allogeneic blood progenitor-cell transplantation as treatment for lymphoid malignancies. J Clin Oncol. 1998; 16(8):2817-24. [PubMed: 9704734]

100. Maris M, Woolfrey A, McSweeney PA, Sandmaier BM, Nash RA, Georges G, Maloney DG, Molina A, Chauncey T, Yu C, Zaucha JM, Blume KG, Shizuru J, Niederwieser D, Storb R. Nonmyeloablative hematopoietic stem cell transplantation: transplantation for the 21 st century. Front Biosci. 2001; 6:G13-6. [PubMed: 11487474]

101. McSweeney PA, Niederwieser D, Shizuru JA, Sandmaier BM, Molina AJ, Maloney DG, Chauncey TR, Gooley TA, Hegenbart U, Nash RA, Radich J, Wagner JL, Minor S, Appelbaum FR, Bensinger WI, Bryant E, Flowers ME, Georges GE, Grumet FC, Kiem HP, Torok-Storb B, Yu C, Blume KG, Storb RF. Hematopoietic cell transplantation in older patients with hematologic malignancies: replacing high-dose cytotoxic therapy with graft-versus-tumor effects. Blood. 2001; 97(11):3390-400. [PubMed: 11369628]

102. Mielcarek M, Sandmaier BM, Maloney DG, Maris M, McSweeney PA, Woolfrey A, Chauncey T, Feinstein L, Niederwieser D, Blume KG, Forman S, Torok-Storb B, Storb R. Nonmyeloablative hematopoietic cell transplantation: status quo and future perspectives. J Clin Immunol. 2002; 22(2):70-4. [PubMed: 11998895]

103. Slavin S, Nagler A, Naparstek E, Kapelushnik Y, Aker M, Cividalli G, Varadi G, Kirschbaum M, Ackerstein A, Samuel S, Amar A, Brautbar C, Ben-Tal O, Eldor A, Or R. Nonmyeloablative stem cell transplantation and cell therapy as an alternative to conventional bone marrow transplantation with lethal cytoreduction for the treatment of malignant and nonmalignant hematologic diseases. Blood. 1998; 91(3):756-63. [PubMed: 9446633] 
104. Anasetti C, Logan BR, Lee SJ, Waller EK, Weisdorf DJ, Wingard JR, Cutler CS, Westervelt P, Woolfrey A, Couban S, Ehninger G, Johnston L, Maziarz RT, Pulsipher MA, Porter DL, Mineishi S, McCarty JM, Khan SP, Anderlini P, Bensinger WI, Leitman SF, Rowley SD, Bredeson C, Carter SL, Horowitz MM, Confer DL. Peripheral-blood stem cells versus bone marrow from unrelated donors. N Engl J Med. 2012; 367(16):1487-96. [PubMed: 23075175]

105. Zander AR, Dicke KA, Verma D, Ginzbarg S, Spitzer G. Mobilization of murine hemopoietic stem cells (HSC) by Pyran Copolymer. Exp Hematol. 1979; 7(Suppl 5):116-24. [PubMed: 263238]

106. Zander AR, Templeton J, Gray KN, Spitzer G, Verma DS, Dicke KA. Mobilization of canine hemopoietic stem cells by pyran copolymer (NSC 46015). Biomed Pharmacother. 1984; 38(2): 107-10. [PubMed: 6743771]

107. Zander AR, Spitzer G, Verma DS, Ginzbarg S, Dicke KA. Pyran copolymer: effect of molecular weight on stem cell mobilization in mice. Biomedicine. 1980; 33(3):69-72. [PubMed: 7448325]

108. Drize N, Chertkov J, Zander A. Hematopoietic progenitor cell mobilization into the peripheral blood of mice using a combination of recombinant rat stem cell factor (rrSCF) and recombinant human granulocyte colony-stimulating factor (rhG-CSF). Exp Hematol. 1995; 23(11):1180-6. [PubMed: 7556528]

109. Chen BP, Fraser C, Reading C, Murray L, Uchida N, Galy A, Sasaki D, Tricot G, Jagannath S, Barlogie B, et al. Cytokine-mobilized peripheral blood CD34+Thy-1+Lin- human hematopoietic stem cells as target cells for transplantation-based gene therapy. Leukemia. 1995; 9(Suppl 1):S17-25. [PubMed: 7475307]

110. Junker U, Moon JJ, Kalfoglou CS, Sniecinski I, Forman SJ, Zaia JA, Kaneshima H, Bohnlein E. Hematopoietic potential and retroviral transduction of CD34+ Thy-1+ peripheral blood stem cells from asymptomatic human immunodeficiency virus type-1-infected individuals mobilized with granulocyte colony-stimulating factor. Blood. 1997; 89(12):4299-306. [PubMed: 9192752]

111. Murray L, Chen B, Galy A, Chen S, Tushinski R, Uchida N, Negrin R, Tricot G, Jagannath S, Vesole D, et al. Enrichment of human hematopoietic stem cell activity in the CD34+Thy-1+Linsubpopulation from mobilized peripheral blood. Blood. 1995; 85(2):368-78. [PubMed: 7529060]

112. Murray LJ, Tsukamoto A, Hoffman R. CD34+Thy-1+Lin- stem cells from mobilized peripheral blood. Leuk Lymphoma. 1996; 22(1-2):37-42. follow 186, color plate I. [PubMed: 8724526]

113. Van den Berg D, Wessman M, Murray L, Tong J, Chen B, Chen S, Simonetti D, King J, Yamasaki G, DiGiusto R, Gearing D, Reading C. Leukemic burden in subpopulations of CD34+ cells isolated from the mobilized peripheral blood of alpha-interferon-resistant or -intolerant patients with chronic myeloid leukemia. Blood. 1996; 87(10):4348-57. [PubMed: 8639795]

114. Bensinger WI, Martin PJ, Storer B, Clift R, Forman SJ, Negrin R, Kashyap A, Flowers ME, Lilleby K, Chauncey TR, Storb R, Appelbaum FR. Transplantation of bone marrow as compared with peripheral-blood cells from HLA-identical relatives in patients with hematologic cancers. N Engl J Med. 2001; 344(3):175-81. [PubMed: 11172139]

115. Bensinger WI, Weaver CH, Appelbaum FR, Rowley S, Demirer T, Sanders J, Storb R, Buckner CD. Transplantation of allogeneic peripheral blood stem cells mobilized by recombinant human granulocyte colony-stimulating factor. Blood. 1995; 85(6):1655-8. [PubMed: 7534140]

116. Gianni AM, Siena S, Bregni M, Tarella C, Stern AC, Pileri A, Bonadonna G. Granulocytemacrophage colony-stimulating factor to harvest circulating haemopoietic stem cells for autotransplantation. Lancet. 1989; 2(8663):580-5. [PubMed: 2570283]

117. Juttner CA, To LB, Ho JQ, Bardy PG, Dyson PG, Haylock DN, Kimber RJ. Early lymphohemopoietic recovery after autografting using peripheral blood stem cells in acute nonlymphoblastic leukemia. Transplant Proc. 1988; 20(1):40-2. [PubMed: 2894085]

118. Korbling M, Champlin R. Peripheral blood progenitor cell transplantation: a replacement for marrow auto- or allografts. Stem Cells. 1996; 14(2):185-95. [PubMed: 8991538]

119. Schmitz N, Linch DC, Dreger P, Goldstone AH, Boogaerts MA, Ferrant A, Demuynck HM, Link $\mathrm{H}$, Zander A, Barge A. Randomised trial of filgrastim-mobilised peripheral blood progenitor cell transplantation versus autologous bone-marrow transplantation in lymphoma patients. Lancet. 1996; 347(8998):353-7. [PubMed: 8598700] 
120. Jantunen E, Varmavuo V. Plerixafor for mobilization of blood stem cells in autologous transplantation: an update. Expert Opin Biol Ther. 2014; 14(6):851-61. [PubMed: 24673120]

121. Dreger P, Suttorp M, Haferlach T, Loffler H, Schmitz N, Schroyens W. Allogeneic granulocyte colony-stimulating factor-mobilized peripheral blood progenitor cells for treatment of engraftment failure after bone marrow transplantation. Blood. 1993; 81(5):1404-7. [PubMed: 7680245]

122. Korbling M, Przepiorka D, Huh YO, Engel H, van Besien K, Giralt S, Andersson B, Kleine HD, Seong D, Deisseroth AB, et al. Allogeneic blood stem cell transplantation for refractory leukemia and lymphoma: potential advantage of blood over marrow allografts. Blood. 1995; 85(6):165965. [PubMed: 7888684]

123. Russell NH, Hunter A, Rogers S, Hanley J, Anderson D. Peripheral blood stem cells as an alternative to marrow for allogeneic transplantation. Lancet. 1993; 341(8858):1482. [PubMed: 8099182]

124. Schmitz N, Dreger P, Suttorp M, Rohwedder EB, Haferlach T, Loffler H, Hunter A, Russell NH. Primary transplantation of allogeneic peripheral blood progenitor cells mobilized by filgrastim (granulocyte colony-stimulating factor). Blood. 1995; 85(6):1666-72. [PubMed: 7534141]

125. Stem Cell Trialist's Collaborative Group: Allogeneic peripheral blood stem-cell compared with bone marrow transplantation in the management of hematologic malignancies: an individual patient data meta-analysis of nine randomized trials. J Clin Oncol. 2005; 23(22):5074-87. [PubMed: 16051954]

126. Pidala J, Anasetti C, Kharfan-Dabaja MA, Cutler C, Sheldon A, Djulbegovic B. Decision analysis of peripheral blood versus bone marrow hematopoietic stem cells for allogeneic hematopoietic cell transplantation. Biol Blood Marrow Transplant. 2009; 15(11):1415-21. [PubMed: 19822301]

127. Blaise D, Kuentz M, Fortanier C, Bourhis JH, Milpied N, Sutton L, Jouet JP, Attal M, Bordigoni P, Cahn JY, Boiron JM, Schuller MP, Moatti JP, Michallet M. Randomized trial of bone marrow versus lenograstim-primed blood cell allogeneic transplantation in patients with early-stage leukemia: a report from the Societe Francaise de Greffe de Moelle. J Clin Oncol. 2000; 18(3): 537-46. [PubMed: 10653869]

128. Couban S, Simpson DR, Barnett MJ, Bredeson C, Hubesch L, Howson-Jan K, Shore TB, Walker IR, Browett P, Messner HA, Panzarella T, Lipton JH. A randomized multicenter comparison of bone marrow and peripheral blood in recipients of matched sibling allogeneic transplants for myeloid malignancies. Blood. 2002; 100(5):1525-31. [PubMed: 12176866]

129. Morton J, Hutchins C, Durrant S. Granulocyte-colony-stimulating factor (G-CSF)-primed allogeneic bone marrow: significantly less graft-versus-host disease and comparable engraftment to G-CSF-mobilized peripheral blood stem cells. Blood. 2001; 98(12):3186-91. [PubMed: 11719353]

130. Powles R, Mehta J, Kulkarni S, Treleaven J, Millar B, Marsden J, Shepherd V, Rowland A, Sirohi B, Tait D, Horton C, Long S, Singhal S. Allogeneic blood and bone-marrow stem-cell transplantation in haematological malignant diseases: a randomised trial. Lancet. 2000; 355(9211):1231-7. [PubMed: 10770306]

131. Schmitz N, Beksac M, Hasenclever D, Bacigalupo A, Ruutu T, Nagler A, Gluckman E, Russell N, Apperley JF, Gorin NC, Szer J, Bradstock K, Buzyn A, Clark P, Borkett K, Gratwohl A. Transplantation of mobilized peripheral blood cells to HLA-identical siblings with standard-risk leukemia. Blood. 2002; 100(3):761-7. [PubMed: 12130483]

132. Eapen M, Logan BR, Confer DL, Haagenson M, Wagner JE, Weisdorf DJ, Wingard JR, Rowley SD, Stroncek D, Gee AP, Horowitz MM, Anasetti C. Peripheral blood grafts from unrelated donors are associated with increased acute and chronic graft-versus-host disease without improved survival. Biol Blood Marrow Transplant. 2007; 13(12):1461-8. [PubMed: 18022576]

133. Iravani M, Tavakoli E, Babaie MH, Ashouri A, Khatami F, Ghavamzadeh A. Comparison of peripheral blood stem cell transplant with bone marrow transplant in class 3 thalassemic patients. Exp Clin Transplant. 2010; 8(1):66-73. [PubMed: 20199374]

134. Ghavamzadeh A, Iravani M, Ashouri A, Mousavi SA, Mahdavi N, Shamshiri A, Hadjibabaie M, Namdar R, Nedaeifard L, Ghaffari H, Alimoghaddam K. Peripheral blood versus bone marrow as a source of hematopoietic stem cells for allogeneic transplantation in children with class I and II beta thalassemia major. Biol Blood Marrow Transplant. 2008; 14(3):301-8. [PubMed: 18275896] 
135. Holtick U, Albrecht M, Chemnitz JM, Theurich S, Skoetz N, Scheid C, von Bergwelt-Baildon M. Bone marrow versus peripheral blood allogeneic haematopoietic stem cell transplantation for haematological malignancies in adults. Cochrane Database Syst Rev. 2014; 4:CD010189. [PubMed: 24748537]

136. Flowers ME, Parker PM, Johnston LJ, Matos AV, Storer B, Bensinger WI, Storb R, Appelbaum FR, Forman SJ, Blume KG, Martin PJ. Comparison of chronic graft-versus-host disease after transplantation of peripheral blood stem cells versus bone marrow in allogeneic recipients: longterm follow-up of a randomized trial. Blood. 2002; 100(2):415-9. [PubMed: 12091330]

137. Friedrichs B, Tichelli A, Bacigalupo A, Russell NH, Ruutu T, Shapira MY, Beksac M, Hasenclever D, Socie G, Schmitz N. Long-term outcome and late effects in patients transplanted with mobilised blood or bone marrow: a randomised trial. Lancet Oncol. 2010; 11(4):331-8. [PubMed: 20117965]

138. Petersdorf EW, Hansen JA, Martin PJ, Woolfrey A, Malkki M, Gooley T, Storer B, Mickelson E, Smith A, Anasetti C. Major-histocompatibility-complex class I alleles and antigens in hematopoietic-cell transplantation. N Engl J Med. 2001; 345(25):1794-800. [PubMed: 11752355]

139. Sierra J, Storer B, Hansen JA, Bjerke JW, Martin PJ, Petersdorf EW, Appelbaum FR, Bryant E, Chauncey TR, Sale G, Sanders JE, Storb R, Sullivan KM, Anasetti C. Transplantation of marrow cells from unrelated donors for treatment of high-risk acute leukemia: the effect of leukemic burden, donor HLA-matching, and marrow cell dose. Blood. 1997; 89(11):4226-35. [PubMed: 9166868]

140. Spellman S, Bray R, Rosen-Bronson S, Haagenson M, Klein J, Flesch S, Vierra-Green C, Anasetti C. The detection of donor-directed, HLA-specific alloantibodies in recipients of unrelated hematopoietic cell transplantation is predictive of graft failure. Blood. 2010; 115(13): 2704-8. [PubMed: 20089963]

141. Guardiola P, Runde V, Bacigalupo A, Ruutu T, Locatelli F, Boogaerts MA, Pagliuca A, Cornelissen JJ, Schouten HC, Carreras E, Finke J, van Biezen A, Brand R, Niederwieser D, Gluckman E, de Witte TM. Retrospective comparison of bone marrow and granulocyte colonystimulating factor-mobilized peripheral blood progenitor cells for allogeneic stem cell transplantation using HLA identical sibling donors in myelodysplastic syndromes. Blood. 2002; 99(12):4370-8. [PubMed: 12036864]

142. Ende M, Ende N. Hematopoietic transplantation by means of fetal (cord) blood. A new method. Va Med Mon (1918). 1972; 99(3):276-80. [PubMed: 4502979]

143. Nakahata T, Ogawa M. Hemopoietic colony-forming cells in umbilical cord blood with extensive capability to generate mono- and multipotential hemopoietic progenitors. J Clin Invest. 1982; 70(6):1324-8. [PubMed: 7174797]

144. Broxmeyer HE, Douglas GW, Hangoc G, Cooper S, Bard J, English D, Arny M, Thomas L, Boyse EA. Human umbilical cord blood as a potential source of transplantable hematopoietic stem/progenitor cells. Proc Natl Acad Sci U S A. 1989; 86(10):3828-32. [PubMed: 2566997]

145. Gluckman E, Ruggeri A, Volt F, Cunha R, Boudjedir K, Rocha V. Milestones in umbilical cord blood transplantation. Br J Haematol. 2011; 154(4):441-7. [PubMed: 21726206]

146. Smith S, Broxmeyer HE. The influence of oxygen tension on the long-term growth in vitro of haematopoietic progenitor cells from human cord blood. Br J Haematol. 1986; 63(1):29-34. [PubMed: 3707863]

147. Gluckman E, Broxmeyer HA, Auerbach AD, Friedman HS, Douglas GW, Devergie A, Esperou H, Thierry D, Socie G, Lehn P, Cooper S, English D, Kurtzberg J, Bard J, Boyse EA. Hematopoietic reconstitution in a patient with Fanconi's anemia by means of umbilical-cord blood from an HLA-identical sibling. N Engl J Med. 1989; 321(17):1174-8. [PubMed: 2571931]

148. Auerbach AD, Adler B, Chaganti RS. Prenatal and postnatal diagnosis and carrier detection of Fanconi anemia by a cytogenetic method. Pediatrics. 1981; 67(1):128-35. [PubMed: 7243421]

149. Auerbach AD, Sagi M, Adler B. Fanconi anemia: prenatal diagnosis in 30 fetuses at risk. Pediatrics. 1985; 76(5):794-800. [PubMed: 4058989]

150. Gluckman E, Devergie A, Dutreix J. Radiosensitivity in Fanconi anaemia: application to the conditioning regimen for bone marrow transplantation. Br J Haematol. 1983; 54(3):431-40. [PubMed: 6344915] 
151. Gluckman E, Devergie A, Bourdeau-Esperou H, Thierry D, Traineau R, Auerbach A, Broxmeyer HE. Transplantation of umbilical cord blood in Fanconi's anemia. Nouv Rev Fr Hematol. 1990; 32(6):423-5. [PubMed: 1983224]

152. Ballen KK, Gluckman E, Broxmeyer HE. Umbilical cord blood transplantation: the first 25 years and beyond. Blood. 2013; 122(4):491-8. [PubMed: 23673863]

153. Danby R, Rocha V. Improving Engraftment and Immune Reconstitution in Umbilical Cord Blood Transplantation. Front Immunol. 2014; 5:68. [PubMed: 24605111]

154. Broxmeyer, HE. StemBook. Cambridge (MA): 2008. Cord blood hematopoietic stem cell transplantation.

155. Broxmeyer, HE. Cord blood hematopoietic stem cell transplantation. 2008.

156. Barker JN, Weisdorf DJ, DeFor TE, Blazar BR, McGlave PB, Miller JS, Verfaillie CM, Wagner JE. Transplantation of 2 partially HLA-matched umbilical cord blood units to enhance engraftment in adults with hematologic malignancy. Blood. 2005; 105(3):1343-7. [PubMed: 15466923]

157. Lister J, Gryn JF, McQueen KL, Harris DT, Rossetti JM, Shadduck RK. Multiple unit HLAunmatched sex-mismatched umbilical cord blood transplantation for advanced hematological malignancy. Stem Cells Dev. 2007; 16(1):177-86. [PubMed: 17348813]

158. Zanjani ED, Almeida-Porada G, Ascensao JL, MacKintosh FR, Flake AW. Transplantation of hematopoietic stem cells in utero. Stem Cells. 1997; 15(Suppl 1):79-92. discussion 93. [PubMed: 9368328]

159. Zanjani ED, Almeida-Porada G, Livingston AG, Porada CD, Ogawa M. Engraftment and multilineage expression of human bone marrow CD34- cells in vivo. Ann N Y Acad Sci. 1999; 872:220-31. discussion 231-2. [PubMed: 10372125]

160. Almeida-Porada G, Flake AW, Glimp HA, Zanjani ED. Cotransplantation of stroma results in enhancement of engraftment and early expression of donor hematopoietic stem cells in utero. Exp Hematol. 1999; 27(10):1569-75. [PubMed: 10517499]

161. Aggarwal R, Lu J, Kanji S, Joseph M, Das M, Noble GJ, McMichael BK, Agarwal S, Hart RT, Sun Z, Lee BS, Rosol TJ, Jackson R, Mao HQ, Pompili VJ, Das H. Human umbilical cord bloodderived CD34+ cells reverse osteoporosis in NOD/SCID mice by altering osteoblastic and osteoclastic activities. PLoS One. 2012; 7(6):e39365. [PubMed: 22724005]

162. Chua KN, Chai C, Lee PC, Ramakrishna S, Leong KW, Mao HQ. Functional nanofiber scaffolds with different spacers modulate adhesion and expansion of cryopreserved umbilical cord blood hematopoietic stem/progenitor cells. Exp Hematol. 2007; 35(5):771-81. [PubMed: 17577926]

163. Lu J, Aggarwal R, Pompili VJ, Das H. A novel technology for hematopoietic stem cell expansion using combination of nanofiber and growth factors. Recent Pat Nanotechnol. 2010; 4(2):125-35. [PubMed: 20420564]

164. Peled T, Mandel J, Goudsmid RN, Landor C, Hasson N, Harati D, Austin M, Hasson A, Fibach E, Shpall EJ, Nagler A. Pre-clinical development of cord blood-derived progenitor cell graft expanded ex vivo with cytokines and the polyamine copper chelator tetraethylenepentamine. Cytotherapy. 2004; 6(4):344-55. [PubMed: 16146887]

165. Zaker F, Nasiri N, Oodi A, Amirizadeh N. Evaluation of umbilical cord blood CD34 (+) hematopoietic stem cell expansion in co-culture with bone marrow mesenchymal stem cells in the presence of TEPA. Hematology. 2013; 18(1):39-45. [PubMed: 23321686]

166. Abe T, Masuda S, Ban H, Hayashi S, Ueda Y, Inoue M, Hasegawa M, Nagao Y, Hanazono Y. Ex vivo expansion of human HSCs with Sendai virus vector expressing HoxB4 assessed by sheep in utero transplantation. Exp Hematol. 2011; 39(1):47-54. [PubMed: 20875838]

167. Gallagher RC, Tura-Ceide O, Turner M, Barclay R. Analysis of Wnt pathway genes during ex vivo expansion and neutrophil differentiation of umbilical-cord-blood-derived CD34 cells. Vox Sang. 2010; 98(3 Pt 1):e290-4. [PubMed: 20059757]

168. Lessard J, Faubert A, Sauvageau G. Genetic programs regulating HSC specification, maintenance and expansion. Oncogene. 2004; 23(43):7199-209. [PubMed: 15378080]

169. Schiedlmeier B, Klump H, Will E, Arman-Kalcek G, Li Z, Wang Z, Rimek A, Friel J, Baum C, Ostertag W. High-level ectopic HOXB4 expression confers a profound in vivo competitive 
growth advantage on human cord blood CD34+ cells, but impairs lymphomyeloid differentiation. Blood. 2003; 101(5):1759-68. [PubMed: 12406897]

170. Sekulovic S, Gasparetto M, Lecault V, Hoesli CA, Kent DG, Rosten P, Wan A, Brookes C, Hansen CL, Piret JM, Smith C, Eaves CJ, Humphries RK. Ontogeny stage-independent and highlevel clonal expansion in vitro of mouse hematopoietic stem cells stimulated by an engineered NUP98-HOX fusion transcription factor. Blood. 2011; 118(16):4366-76. [PubMed: 21865344]

171. Suzuki K, Ono R, Ohishi K, Masuya M, Kataoka I, Liu B, Nakamori Y, Ino K, Monma F, Hamada H, Kitamura T, Katayama N, Nosaka T. IKAROS isoform 6 enhances BCR-ABL1mediated proliferation of human CD34+ hematopoietic cells on stromal cells. Int J Oncol. 2012; 40(1):53-62. [PubMed: 21901249]

172. Tanaka H, Matsumura I, Itoh K, Hatsuyama A, Shikamura M, Satoh Y, Heike T, Nakahata T, Kanakura Y. HOX decoy peptide enhances the ex vivo expansion of human umbilical cord blood CD34+ hematopoietic stem cells/hematopoietic progenitor cells. Stem Cells. 2006; 24(11):2592602. [PubMed: 17071861]

173. Watts KL, Nelson V, Wood BL, Trobridge GD, Beard BC, Humphries RK, Kiem HP. Hematopoietic stem cell expansion facilitates multilineage engraftment in a nonhuman primate cord blood transplantation model. Exp Hematol. 2012; 40(3):187-96. [PubMed: 22155723]

174. Zhang XB, Beard BC, Beebe K, Storer B, Humphries RK, Kiem HP. Differential effects of HOXB4 on nonhuman primate short- and long-term repopulating cells. PLoS Med. 2006; 3(5):e173. [PubMed: 16637742]

175. Mahmud N, Petro B, Baluchamy S, Li X, Taioli S, Lavelle D, Quigley JG, Suphangul M, Araki H. Differential effects of epigenetic modifiers on the expansion and maintenance of human cord blood stem/progenitor cells. Biol Blood Marrow Transplant. 2014; 20(4):480-9. [PubMed: 24374212]

176. van Galen P, Kreso A, Wienholds E, Laurenti E, Eppert K, Lechman ER, Mbong N, Hermans K, Dobson S, April C, Fan JB, Dick JE. Reduced lymphoid lineage priming promotes human hematopoietic stem cell expansion. Cell Stem Cell. 2014; 14(1):94-106. [PubMed: 24388174]

177. Andrade PZ, dos Santos F, Almeida-Porada G, da Silva CL, Cabral JMS. Systematic delineation of optimal cytokine concentrations to expand hematopoietic stem/progenitor cells in co-culture with mesenchymal stem cells. Mol Biosyst. 2010; 6(7):1207-15. [PubMed: 20424784]

178. Brandt JE, Bartholomew AM, Fortman JD, Nelson MC, Bruno E, Chen LM, Turian JV, Davis TA, Chute JP, Hoffman R. Ex vivo expansion of autologous bone marrow CD34(+) cells with porcine microvascular endothelial cells results in a graft capable of rescuing lethally irradiated baboons. Blood. 1999; 94(1):106-13. [PubMed: 10381503]

179. Brandt JE, Galy AH, Luens KM, Travis M, Young J, Tong J, Chen S, Davis TA, Lee KP, Chen BP, Tushinski R, Hoffman R. Bone marrow repopulation by human marrow stem cells after longterm expansion culture on a porcine endothelial cell line. Exp Hematol. 1998; 26(10):950-61. [PubMed: 9728930]

180. Frias AM, Porada CD, Crapnell KB, Cabral JM, Zanjani ED, Almeida-Porada G. Generation of functional natural killer and dendritic cells in a human stromal-based serum-free culture system designed for cord blood expansion. Exp Hematol. 2008; 36(1):61-8. [PubMed: 18155552]

181. de Lima M, McNiece I, Robinson SN, Munsell M, Eapen M, Horowitz M, Alousi A, Saliba R, McMannis JD, Kaur I, Kebriaei P, Parmar S, Popat U, Hosing C, Champlin R, Bollard C, Molldrem JJ, Jones RB, Nieto Y, Andersson BS, Shah N, Oran B, Cooper LJ, Worth L, Qazilbash MH, Korbling M, Rondon G, Ciurea S, Bosque D, Maewal I, Simmons PJ, Shpall EJ. Cord-blood engraftment with ex vivo mesenchymal-cell coculture. N Engl J Med. 2012; 367(24):2305-15. [PubMed: 23234514]

182. Holmes T, Yan F, Ko KH, Nordon R, Song E, O'Brien TA, Dolnikov A. Ex vivo expansion of cord blood progenitors impairs their short-term and long-term repopulating activity associated with transcriptional dysregulation of signalling networks. Cell Prolif. 2012; 45(3):266-78. [PubMed: 22429797]

183. Huang GP, Pan ZJ, Jia BB, Zheng Q, Xie CG, Gu JH, McNiece IK, Wang JF. Ex vivo expansion and transplantation of hematopoietic stem/progenitor cells supported by mesenchymal stem cells from human umbilical cord blood. Cell Transplant. 2007; 16(6):579-85. [PubMed: 17912949] 
184. Guenechea G, Segovia JC, Albella B, Lamana M, Ramirez M, Regidor C, Fernandez MN, Bueren JA. Delayed engraftment of nonobese diabetic/severe combined immunodeficient mice transplanted with ex vivo-expanded human CD34(+) cord blood cells. Blood. 1999; 93(3):1097105. [PubMed: 9920860]

185. Szilvassy SJ, Bass MJ, Van Zant G, Grimes B. Organ-selective homing defines engraftment kinetics of murine hematopoietic stem cells and is compromised by Ex vivo expansion. Blood. 1999; 93(5):1557-66. [PubMed: 10029584]

186. McNiece IK, Almeida-Porada G, Shpall EJ, Zanjani E. Ex vivo expanded cord blood cells provide rapid engraftment in fetal sheep but lack long-term engrafting potential. Exp Hematol. 2002; 30(6):612-6. [PubMed: 12063029]

187. Horwitz ME, Frassoni F. Improving the outcome of umbilical cord blood transplantation through ex vivo expansion or graft manipulation. Cytotherapy. 2015; 17(6):730-8. [PubMed: 25778757]

188. Chicha L, Feki A, Boni A, Irion O, Hovatta O, Jaconi M. Human pluripotent stem cells differentiated in fully defined medium generate hematopoietic CD34- and CD34+ progenitors with distinct characteristics. PLoS One. 2011; 6(2):e14733. [PubMed: 21364915]

189. Klump H, Teichweyde N, Meyer C, Horn PA. Development of patient-specific hematopoietic stem and progenitor cell grafts from pluripotent stem cells, in vitro. Curr Mol Med. 2013; 13(5): 815-20. [PubMed: 23642062]

190. Niwa A, Heike T, Umeda K, Oshima K, Kato I, Sakai H, Suemori H, Nakahata T, Saito MK. A novel serum-free monolayer culture for orderly hematopoietic differentiation of human pluripotent cells via mesodermal progenitors. PLoS One. 2011; 6(7):e22261. [PubMed: 21818303]

191. Niwa A, Umeda K, Chang H, Saito M, Okita K, Takahashi K, Nakagawa M, Yamanaka S, Nakahata T, Heike T. Orderly hematopoietic development of induced pluripotent stem cells via Flk-1(+) hemoangiogenic progenitors. J Cell Physiol. 2009; 221(2):367-77. [PubMed: 19562687]

192. Pearson S, Sroczynska P, Lacaud G, Kouskoff V. The stepwise specification of embryonic stem cells to hematopoietic fate is driven by sequential exposure to Bmp4, activin A, bFGF and VEGF. Development. 2008; 135(8):1525-35. [PubMed: 18339678]

193. Sroczynska P, Lancrin C, Pearson S, Kouskoff V, Lacaud G. In vitro differentiation of mouse embryonic stem cells as a model of early hematopoietic development. Methods Mol Biol. 2009; 538:317-34. [PubMed: 19277585]

194. Dravid GG, Crooks GM. The challenges and promises of blood engineered from human pluripotent stem cells. Adv Drug Deliv Rev. 2011; 63(4-5):331-41. [PubMed: 21232565]

195. van Bekkum DW, Mikkers HM. Prospects and challenges of induced pluripotent stem cells as a source of hematopoietic stem cells. Ann N Y Acad Sci. 2012; 1266:179-88. [PubMed: 22901269]

196. Blasco MA, Serrano M, Fernandez-Capetillo O. Genomic instability in iPS: time for a break. EMBO J. 2011; 30(6):991-3. [PubMed: 21407252]

197. Gore A, Li Z, Fung HL, Young JE, Agarwal S, Antosiewicz-Bourget J, Canto I, Giorgetti A, Israel MA, Kiskinis E, Lee JH, Loh YH, Manos PD, Montserrat N, Panopoulos AD, Ruiz S, Wilbert ML, Yu J, Kirkness EF, Izpisua Belmonte JC, Rossi DJ, Thomson JA, Eggan K, Daley GQ, Goldstein LS, Zhang K. Somatic coding mutations in human induced pluripotent stem cells. Nature. 2011; 471(7336):63-7. [PubMed: 21368825]

198. Hussein SM, Batada NN, Vuoristo S, Ching RW, Autio R, Narva E, Ng S, Sourour M, Hamalainen R, Olsson C, Lundin K, Mikkola M, Trokovic R, Peitz M, Brustle O, Bazett-Jones DP, Alitalo K, Lahesmaa R, Nagy A, Otonkoski T. Copy number variation and selection during reprogramming to pluripotency. Nature. 2011; 471(7336):58-62. [PubMed: 21368824]

199. Laurent LC, Ulitsky I, Slavin I, Tran H, Schork A, Morey R, Lynch C, Harness JV, Lee S, Barrero MJ, Ku S, Martynova M, Semechkin R, Galat V, Gottesfeld J, Izpisua Belmonte JC, Murry C, Keirstead HS, Park HS, Schmidt U, Laslett AL, Muller FJ, Nievergelt CM, Shamir R, Loring JF. Dynamic changes in the copy number of pluripotency and cell proliferation genes in human ESCs and iPSCs during reprogramming and time in culture. Cell Stem Cell. 2011; 8(1):106-18. [PubMed: 21211785] 
200. Hanna J, Wernig M, Markoulaki S, Sun CW, Meissner A, Cassady JP, Beard C, Brambrink T, Wu LC, Townes TM, Jaenisch R. Treatment of sickle cell anemia mouse model with iPS cells generated from autologous skin. Science. 2007; 318(5858):1920-3. [PubMed: 18063756]

201. Hexum MK, Tian X, Kaufman DS. In vivo evaluation of putative hematopoietic stem cells derived from human pluripotent stem cells. Methods Mol Biol. 2011; 767:433-47. [PubMed: 21822894]

202. Sakamoto H, Tsuji-Tamura K, Ogawa M. Hematopoiesis from pluripotent stem cell lines. Int J Hematol. 2010; 91(3):384-91. [PubMed: 20169427]

203. Szabo E, Rampalli S, Risueno RM, Schnerch A, Mitchell R, Fiebig-Comyn A, Levadoux-Martin M, Bhatia M. Direct conversion of human fibroblasts to multilineage blood progenitors. Nature. 2010; 468(7323):521-6. [PubMed: 21057492]

204. Woods NB, Parker AS, Moraghebi R, Lutz MK, Firth AL, Brennand KJ, Berggren WT, Raya A, Belmonte JC, Gage FH, Verma IM. Brief report: efficient generation of hematopoietic precursors and progenitors from human pluripotent stem cell lines. Stem Cells. 2011; 29(7):1158-64. [PubMed: 21544903]

205. Irion S, Clarke RL, Luche H, Kim I, Morrison SJ, Fehling HJ, Keller GM. Temporal specification of blood progenitors from mouse embryonic stem cells and induced pluripotent stem cells. Development. 2010; 137(17):2829-39. [PubMed: 20659975]

206. Lengerke C, Daley GQ. Autologous blood cell therapies from pluripotent stem cells. Blood Rev. 2010; 24(1):27-37. [PubMed: 19910091]

207. Lengerke C, Grauer M, Niebuhr NI, Riedt T, Kanz L, Park IH, Daley GQ. Hematopoietic development from human induced pluripotent stem cells. Annals of the New York Academy of Sciences. 2009; 1176:219-27. [PubMed: 19796250]

208. Risueno RM, Sachlos E, Lee JH, Lee JB, Hong SH, Szabo E, Bhatia M. Inability of human induced pluripotent stem cell-hematopoietic derivatives to downregulate microRNAs in vivo reveals a block in xenograft hematopoietic regeneration. Stem Cells. 2012; 30(2):131-9. [PubMed: 22131151]

209. Jandial R, Levy ML. Cellular alchemy: induced pluripotent stem cells retain epigenetic memory. World Neurosurg. 2011; 75(1):5-6. [PubMed: 21492641]

210. Ohi Y, Qin H, Hong C, Blouin L, Polo JM, Guo T, Qi Z, Downey SL, Manos PD, Rossi DJ, Yu J, Hebrok M, Hochedlinger K, Costello JF, Song JS, Ramalho-Santos M. Incomplete DNA methylation underlies a transcriptional memory of somatic cells in human iPS cells. Nat Cell Biol. 2011; 13(5):541-9. [PubMed: 21499256]

211. Polo JM, Liu S, Figueroa ME, Kulalert W, Eminli S, Tan KY, Apostolou E, Stadtfeld M, Li Y, Shioda T, Natesan S, Wagers AJ, Melnick A, Evans T, Hochedlinger K. Cell type of origin influences the molecular and functional properties of mouse induced pluripotent stem cells. Nat Biotechnol. 2010; 28(8):848-55. [PubMed: 20644536]

212. Sullivan GJ, Bai Y, Fletcher J, Wilmut I. Induced pluripotent stem cells: epigenetic memories and practical implications. Mol Hum Reprod. 2010; 16(12):880-5. [PubMed: 21059705]

213. Kim K, Doi A, Wen B, Ng K, Zhao R, Cahan P, Kim J, Aryee MJ, Ji H, Ehrlich LI, Yabuuchi A, Takeuchi A, Cunniff KC, Hongguang H, McKinney-Freeman S, Naveiras O, Yoon TJ, Irizarry RA, Jung N, Seita J, Hanna J, Murakami P, Jaenisch R, Weissleder R, Orkin SH, Weissman IL, Feinberg AP, Daley GQ. Epigenetic memory in induced pluripotent stem cells. Nature. 2010; 467(7313):285-90. [PubMed: 20644535]

214. Quattrocelli M, Palazzolo G, Floris G, Schoffski P, Anastasia L, Orlacchio A, Vandendriessche T, Chuah MK, Cossu G, Verfaillie C, Sampaolesi M. Intrinsic cell memory reinforces myogenic commitment of pericyte-derived iPSCs. J Pathol. 2011; 223(5):593-603. [PubMed: 21341275]

215. Pfaff N, Lachmann N, Kohlscheen S, Sgodda M, Arauzo-Bravo MJ, Greber B, Kues W, Glage S, Baum C, Niemann H, Schambach A, Cantz T, Moritz T. Efficient hematopoietic redifferentiation of induced pluripotent stem cells derived from primitive murine bone marrow cells. Stem Cells Dev. 2012; 21(5):689-701. [PubMed: 21732815]

216. Amabile G, Welner RS, Nombela-Arrieta C, D'Alise AM, Di Ruscio A, Ebralidze AK, Kraytsberg Y, Ye M, Kocher O, Neuberg DS, Khrapko K, Silberstein LE, Tenen DG. In vivo 
generation of transplantable human hematopoietic cells from induced pluripotent stem cells. Blood. 2013; 121(8):1255-64. [PubMed: 23212524]

217. Suzuki N, Yamazaki S, Yamaguchi T, Okabe M, Masaki H, Takaki S, Otsu M, Nakauchi H. Generation of engraftable hematopoietic stem cells from induced pluripotent stem cells by way of teratoma formation. Mol Ther. 2013; 21(7):1424-31. [PubMed: 23670574]

218. Chambers SM, Studer L. Cell fate plug and play: direct reprogramming and induced pluripotency. Cell. 2011; 145(6):827-30. [PubMed: 21663788]

219. Riddell J, Gazit R, Garrison BS, Guo G, Saadatpour A, Mandal PK, Ebina W, Volchkov P, Yuan GC, Orkin SH, Rossi DJ. Reprogramming committed murine blood cells to induced hematopoietic stem cells with defined factors. Cell. 2014; 157(3):549-64. [PubMed: 24766805]

220. Sandler VM, Lis R, Liu Y, Kedem A, James D, Elemento O, Butler JM, Scandura JM, Rafii S. Reprogramming human endothelial cells to haematopoietic cells requires vascular induction. Nature. 2014; 511(7509):312-8. [PubMed: 25030167]

221. Owen RD. Immunogenetic Consequences of Vascular Anastomoses between Bovine Twins. Science. 1945; 102(2651):400-1. [PubMed: 17755278]

222. Billingham RE, Brent L, Medawar PB. Actively acquired tolerance of foreign cells. Nature. 1953; 172(4379):603-6. [PubMed: 13099277]

223. Billingham RE, Brent L, Medawar PB. Quantitative studies on tissue transplantation immunity. II. The origin, strength and duration of actively and adoptively acquired immunity. Proc R Soc Lond B Biol Sci. 1954; 143(910):58-80. [PubMed: 13224651]

224. Anderson A, Billingham R, Lampkin G, Medawar PB. Use of skin grafting to distinguish between monozygotic and dizygotic twins in cattle. Heredity. 1951; 5:379-397.

225. Stone WH, Cragle RG, Swanson EW, Brown DG. Skin Grafts: Delayed Rejection between Pairs of Cattle Twins Showing Erythrocyte Chimerism. Science. 1965; 148(3675):1335-6. [PubMed: 14281713]

226. Summers PM, Shelton JN. Long-term acceptance of full thickness body skin grafts between Bos taurus-Bos indicus chimeric twins. Aust J Exp Biol Med Sci. 1985; 63( Pt 3):329-32. [PubMed: 3904697]

227. Denman AM, Russell AS, Denman EJ. Adoptive transfer of the diseases of New Zealand black mice to normal mouse strains. Clin Exp Immunol. 1969; 5(6):567-95. [PubMed: 4904067]

228. Morton JI, Siegel BV. Transplantation of autoimmune potential. I. Development of antinuclear antibodies in H-2 histocompatible recipients of bone marrow from New Zealand Black mice. Proc Natl Acad Sci U S A. 1974; 71(6):2162-5. [PubMed: 4601580]

229. Morton JI, Siegel BV. Transplantation of autoimmune potential. IV. Reversal of the NZB autoimmune syndrome by bone marrow transplantation. Transplantation. 1979; 27(2):133-4. [PubMed: 380071]

230. Burt RK, Slavin S, Burns WH, Marmont AM. Induction of tolerance in autoimmune diseases by hematopoietic stem cell transplantation: getting closer to a cure? Blood. 2002; 99(3):768-84. [PubMed: 11806976]

231. Tyndall A, Koike T. High-dose immunoablative therapy with hematopoietic stem cell support in the treatment of severe autoimmune disease: current status and future direction. Intern Med. 2002; 41(8):608-12. [PubMed: 12211526]

232. Weissman IL, Shizuru JA. The origins of the identification and isolation of hematopoietic stem cells, and their capability to induce donor-specific transplantation tolerance and treat autoimmune diseases. Blood. 2008; 112(9):3543-53. [PubMed: 18948588]

233. McSweeney PA, Storb R. Mixed chimerism: preclinical studies and clinical applications. Biol Blood Marrow Transplant. 1999; 5(4):192-203. [PubMed: 10465099]

234. Maloney DG, Sandmaier BM, Mackinnon S, Shizuru JA. Non-myeloablative transplantation. Hematology Am Soc Hematol Educ Program. 2002:392-421. [PubMed: 12446434]

235. van Bekkum DW. Stem cell transplantation for autoimmune disorders. Preclinical experiments. Best Pract Res Clin Haematol. 2004; 17(2):201-22. [PubMed: 15302335]

236. Ikehara S, Kawamura M, Takao F, Inaba M, Yasumizu R, Than S, Hisha H, Sugiura K, Koide Y, Yoshida TO, et al. Organ-specific and systemic autoimmune diseases originate from defects in hematopoietic stem cells. Proc Natl Acad Sci U S A. 1990; 87(21):8341-4. [PubMed: 2236044] 
237. Marmont AM, van Lint MT, Gualandi F, Bacigalupo A. Autologous marrow stem cell transplantation for severe systemic lupus erythematosus of long duration. Lupus. 1997; 6(6):5458. [PubMed: 9256315]

238. Eixarch H, Espejo C, Gomez A, Mansilla MJ, Castillo M, Mildner A, Vidal F, Gimeno R, Prinz M, Montalban X, Barquinero J. Tolerance induction in experimental autoimmune encephalomyelitis using non-myeloablative hematopoietic gene therapy with autoantigen. Mol Ther. 2009; 17(5):897-905. [PubMed: 19277013]

239. Elkin G, Prigozhina TB, Slavin S. Prevention of diabetes in nonobese diabetic mice by nonmyeloablative allogeneic bone marrow transplantation. Exp Hematol. 2004; 32(6):579-84. [PubMed: 15183899]

240. Emmanouilidis N, Larsen CP. Induction of chimerism and tolerance using freshly purified or cultured hematopoietic stem cells in nonmyeloablated mice. Methods Mol Med. 2005; 109:45968. [PubMed: 15585938]

241. Guo Z, Wu T, Sozen H, Pan Y, Heuss N, Kalscheuer H, Sutherland DE, Blazar BR, Hering BJ. A substantial level of donor hematopoietic chimerism is required to protect donor-specific islet grafts in diabetic NOD mice. Transplantation. 2003; 75(7):909-15. [PubMed: 12698073]

242. Kawai T, Cosimi AB, Sachs DH. Preclinical and clinical studies on the induction of renal allograft tolerance through transient mixed chimerism. Curr Opin Organ Transplant. 2011; 16(4): 366-71. [PubMed: 21666482]

243. Koporc Z, Pilat N, Nierlich P, Blaha P, Bigenzahn S, Pree I, Selzer E, Sykes M, Muehlbacher F, Wekerle T. Murine mobilized peripheral blood stem cells have a lower capacity than bone marrow to induce mixed chimerism and tolerance. Am J Transplant. 2008; 8(10):2025-36. [PubMed: 18828766]

244. Lee BW, Lee JI, Oh SH, Ahn YR, Chae HY, Lee MS, Lee MK, Kim KW. A more persistent tolerance to islet allografts through bone marrow transplantation in minimal nonmyeloablative conditioning therapy. Transplant Proc. 2005; 37(5):2266-9. [PubMed: 15964395]

245. Liu C, Zhu P, Saito T, Isaka Y, Nagahara Y, Zhuang J, Li XK. Non-myeloablative conditioning is sufficient to induce mixed chimerism and subsequent acceptance of donor specific cardiac and skin grafts. Int Immunopharmacol. 2013; 16(3):392-8. [PubMed: 23428909]

246. Mapara MY, Pelot M, Zhao G, Swenson K, Pearson D, Sykes M. Induction of stable long-term mixed hematopoietic chimerism following nonmyeloablative conditioning with T cell-depleting antibodies, cyclophosphamide, and thymic irradiation leads to donor-specific in vitro and in vivo tolerance. Biol Blood Marrow Transplant. 2001; 7(12):646-55. [PubMed: 11787527]

247. Meng L, Ouyang J, Zhang H, Wen Y, Chen J, Zhou J. Treatment of an autoimmune encephalomyelitis mouse model with nonmyeloablative conditioning and syngeneic bone marrow transplantation. Restor Neurol Neurosci. 2011; 29(3):177-85. [PubMed: 21586824]

248. Nasa Z, Chung JY, Chan J, Toh BH, Alderuccio F. Nonmyeloablative conditioning generates autoantigen-encoding bone marrow that prevents and cures an experimental autoimmune disease. Am J Transplant. 2012; 12(8):2062-71. [PubMed: 22694476]

249. Nikolic B, Onoe T, Takeuchi Y, Khalpey Z, Primo V, Leykin I, Smith RN, Sykes M. Distinct requirements for achievement of allotolerance versus reversal of autoimmunity via nonmyeloablative mixed chimerism induction in NOD mice. Transplantation. 2010; 89(1):23-32. [PubMed: 20061915]

250. Nikolic B, Takeuchi Y, Leykin I, Fudaba Y, Smith RN, Sykes M. Mixed hematopoietic chimerism allows cure of autoimmune diabetes through allogeneic tolerance and reversal of autoimmunity. Diabetes. 2004; 53(2):376-83. [PubMed: 14747288]

251. Nusair S, Gincberg G, Almogi-Hazan O, Breuer R, Or R, Wallach-Dayan SB. Failure of chimerism formation and tolerance induction from Fas ligand mutant bone marrow donors after nonmyeloablative conditioning. Transpl Immunol. 2012; 27(4):184-8. [PubMed: 22801052]

252. Smith-Berdan S, Gille D, Weissman IL, Christensen JL. Reversal of autoimmune disease in lupus-prone New Zealand black/New Zealand white mice by nonmyeloablative transplantation of purified allogeneic hematopoietic stem cells. Blood. 2007; 110(4):1370-8. [PubMed: 17435112]

253. Stephan L, Pichavant C, Bouchentouf M, Mills P, Camirand G, Tagmouti S, Rothstein D, Tremblay JP. Induction of tolerance across fully mismatched barriers by a nonmyeloablative 
treatment excluding antibodies or irradiation use. Cell Transplant. 2006; 15(8-9):835-46. [PubMed: 17269453]

254. Xu H, Zhu Z, Huang Y, Bozulic LD, Hussain LR, Yan J, Ildstad ST. Innate and adaptive immune responses are tolerized in chimeras prepared with nonmyeloablative conditioning. Transplantation. 2012; 93(5):469-76. [PubMed: 22228418]

255. Adamson LA, Huang WC, Breidenbach WC, Rahhal D, Xu H, Huang Y, Pidwell DJ, Wei FC, Tobin G, Ildstad ST. A modified model of hindlimb osteomyocutaneous flap for the study of tolerance to composite tissue allografts. Microsurgery. 2007; 27(7):630-6. [PubMed: 17868137]

256. Kawai T, Cosimi AB, Wee SL, Houser S, Andrews D, Sogawa H, Phelan J, Boskovic S, Nadazdin O, Abrahamian G, Colvin RB, Sach DH, Madsen JC. Effect of mixed hematopoietic chimerism on cardiac allograft survival in cynomolgus monkeys. Transplantation. 2002; 73(11):1757-64. [PubMed: 12084998]

257. Mathes DW, Hwang B, Graves SS, Edwards J, Chang J, Storer BE, Butts-Miwongtum T, Sale GE, Nash RA, Storb R. Tolerance to vascularized composite allografts in canine mixed hematopoietic chimeras. Transplantation. 2011; 92(12):1301-8. [PubMed: 22082819]

258. Murakami T, Cosimi AB, Kawai T. Mixed chimerism to induce tolerance: lessons learned from nonhuman primates. Transplant Rev (Orlando). 2009; 23(1):19-24. [PubMed: 19027614]

259. Nadazdin O, Abrahamian G, Boskovic S, Smith RN, Schoenfeld DA, Madsen JC, Colvin RB, Sachs DH, Cosimi AB, Kawai T. Stem cell mobilization and collection for induction of mixed chimerism and renal allograft tolerance in cynomolgus monkeys. J Surg Res. 2011; 168(2):294300. [PubMed: 20605588]

260. Marmont AM. Stem cell transplantation for severe autoimmune disorders, with special reference to rheumatic diseases. J Rheumatol Suppl. 1997; 48:13-8. [PubMed: 9150112]

261. Marmont AM. Will hematopoietic stem cell transplantation cure human autoimmune diseases? J Autoimmun. 2008; 30(3):145-50. [PubMed: 18222646]

262. Shizuru JA, Jerabek L, Edwards CT, Weissman IL. Transplantation of purified hematopoietic stem cells: requirements for overcoming the barriers of allogeneic engraftment. Biol Blood Marrow Transplant. 1996; 2(1):3-14. [PubMed: 9078349]

263. Fehr T, Sykes M. Clinical experience with mixed chimerism to induce transplantation tolerance. Transpl Int. 2008; 21(12):1118-35. [PubMed: 18954364]

264. Gu W, Hu J, Wang W, Li L, Tang W, Sun S, Cui W, Ye L, Zhang Y, Hong J, Zhu D, Ning G. Diabetic ketoacidosis at diagnosis influences complete remission after treatment with hematopoietic stem cell transplantation in adolescents with type 1 diabetes. Diabetes Care. 2012; 35(7):1413-9. [PubMed: 22723579]

265. Leventhal J, Abecassis M, Miller J, Gallon L, Ravindra K, Tollerud DJ, King B, Elliott MJ, Herzig G, Herzig R, Ildstad ST. Chimerism and tolerance without GVHD or engraftment syndrome in HLA-mismatched combined kidney and hematopoietic stem cell transplantation. Sci Transl Med. 2012; 4(124):124ra28.

266. Leventhal J, Abecassis M, Miller J, Gallon L, Tollerud D, Elliott MJ, Bozulic LD, Houston C, Sustento-Reodica N, Ildstad ST. Tolerance induction in HLA disparate living donor kidney transplantation by donor stem cell infusion: durable chimerism predicts outcome. Transplantation. 2013; 95(1):169-76. [PubMed: 23222893]

267. Vanikar AV, Trivedi HL. Stem cell transplantation in living donor renal transplantation for minimization of immunosuppression. Transplantation. 2012; 94(8):845-50. [PubMed: 22992765]

268. Strober S. Protective conditioning against GVHD and graft rejection after combined organ and hematopoietic cell transplantation. Blood Cells Mol Dis. 2008; 40(1):48-54. [PubMed: 17827036]

269. Buhler LH, Spitzer TR, Sykes M, Sachs DH, Delmonico FL, Tolkoff-Rubin N, Saidman SL, Sackstein R, McAfee S, Dey B, Colby C, Cosimi AB. Induction of kidney allograft tolerance after transient lymphohematopoietic chimerism in patients with multiple myeloma and end-stage renal disease. Transplantation. 2002; 74(10):1405-9. [PubMed: 12451240]

270. Dave SD, Vanikar A, Trivedi HL, Gumber MR, Patel HV, Shah PR, Kute VB. Stem cells versus donor specific transfusions for tolerance induction in living donor renal transplantation: a singlecenter experience. Transplantation. 2013; 95(1):155-60. [PubMed: 23263505] 
271. Vanikar AV, Trivedi HL, Shah PR, Kanodia KV, Patel RD, Modi PR, Dave SD, Singhai AM, Shah VR, Trivedi VB, Shankar V. Single-center experience on renal transplantation in primary focal and segmental glomerulosclerosis using hematopoietic stem cell transplantation in thymus, bone marrow, portal and peripheral circulation. Saudi J Kidney Dis Transpl. 2013; 24(1):15-21. [PubMed: 23354186]

272. Donckier V, Sanchez-Fueyo A, Craciun L, Lucidi V, Buggenhout A, Troisi R, Rogiers X, Bourgeois N, Boon N, Moreno C, Colle I, Van Vlierberghe H, de Hemptinne B, Goldman M. Induction of tolerance in solid organ transplantation: the rationale to develop clinical protocols in liver transplantation. Transplant Proc. 2009; 41(2):603-6. [PubMed: 19328936]

273. Donckier V, Troisi R, Le Moine A, Toungouz M, Ricciardi S, Colle I, Van Vlierberghe H, Craciun L, Libin M, Praet M, Noens L, Stordeur P, Andrien M, Lambermont M, Gelin M, Bourgeois N, Adler M, de Hemptinne B, Goldman M. Early immunosuppression withdrawal after living donor liver transplantation and donor stem cell infusion. Liver Transpl. 2006; 12(10):1523-8. [PubMed: 17004249]

274. Donckier V, Troisi R, Toungouz M, Colle I, Van Vlierberghe H, Jacquy C, Martiat P, Stordeur P, Zhou L, Boon N, Lambermont M, Schandene L, Van Laethem JL, Noens L, Gelin M, de Hemptinne B, Goldman M. Donor stem cell infusion after non-myeloablative conditioning for tolerance induction to HLA mismatched adult living-donor liver graft. Transpl Immunol. 2004; 13(2):139-46. [PubMed: 15380544]

275. Wu SL, Pan CE. Tolerance and chimerism and allogeneic bone marrow/stem cell transplantation in liver transplantation. World J Gastroenterol. 2013; 19(36):5981-7. [PubMed: 24106398]

276. Vanikar AV, Modi PR, Patel RD, Kanodia KV, Shah VR, Trivedi VB, Trivedi HL. Hematopoietic stem cell transplantation in autoimmune diseases: the Ahmedabad experience. Transplant Proc. 2007; 39(3):703-8. [PubMed: 17445577]

277. Vanikar AV, Trivedi HL, Patel RD, Kanodia KV, Modi PR, Shah VR. Allogenic hematopoietic stem cell transplantation in pemphigus vulgaris: a single-center experience. Indian J Dermatol. 2012; 57(1):9-11. [PubMed: 22470200]

278. Blanco Y, Saiz A, Carreras E, Graus F. Autologous haematopoietic-stem-cell transplantation for multiple sclerosis. Lancet Neurol. 2005; 4(1):54-63. [PubMed: 15620857]

279. Burt RK, Traynor AE, Cohen B, Karlin KH, Davis FA, Stefoski D, Terry C, Lobeck L, Russell EJ, Goolsby C, Rosen S, Gordon LI, Keever-Taylor C, Brush M, Fishman M, Burns WH. T celldepleted autologous hematopoietic stem cell transplantation for multiple sclerosis: report on the first three patients. Bone Marrow Transplant. 1998; 21(6):537-41. [PubMed: 9543056]

280. Fassas A, Kazis A. High-dose immunosuppression and autologous hematopoietic stem cell rescue for severe multiple sclerosis. J Hematother Stem Cell Res. 2003; 12(6):701-11. [PubMed: 14977479]

281. Van, Wijmeersch B.; Sprangers, B.; Dubois, B.; Waer, M.; Billiau, AD. Autologous and allogeneic hematopoietic stem cell transplantation for Multiple Sclerosis: perspective on mechanisms of action. J Neuroimmunol. 2008; 197(2):89-98. [PubMed: 18541311]

282. Lu JQ, Joseph JT, Nash RA, Storek J, Stevens AM, Metz LM, Clark AW, Johnson ES, Yong VW. Neuroinflammation and demyelination in multiple sclerosis after allogeneic hematopoietic stem cell transplantation. Arch Neurol. 2010; 67(6):716-22. [PubMed: 20558390]

283. Metz I, Lucchinetti CF, Openshaw H, Garcia-Merino A, Lassmann H, Freedman MS, Atkins HL, Azzarelli B, Kolar OJ, Bruck W. Autologous haematopoietic stem cell transplantation fails to stop demyelination and neurodegeneration in multiple sclerosis. Brain. 2007; 130(Pt 5):1254-62. [PubMed: 17293360]

284. Gandy KL, Weissman IL. Tolerance of allogeneic heart grafts in mice simultaneously reconstituted with purified allogeneic hematopoietic stem cells. Transplantation. 1998; 65(3): 295-304. [PubMed: 9484743]

285. Shizuru JA, Weissman IL, Kernoff R, Masek M, Scheffold YC. Purified hematopoietic stem cell grafts induce tolerance to alloantigens and can mediate positive and negative $\mathrm{T}$ cell selection. Proc Natl Acad Sci U S A. 2000; 97(17):9555-60. [PubMed: 10920206]

286. Fausto N. Liver regeneration: from laboratory to clinic. Liver Transpl. 2001; 7(10):835-44. [PubMed: 11679980] 
287. Fausto N, Campbell JS, Riehle KJ. Liver regeneration. Hepatology. 2006; 43(2 Suppl 1):S45-53. [PubMed: 16447274]

288. Grompe M. Principles of therapeutic liver repopulation. J Inherit Metab Dis. 2006; 29(2-3):4215. [PubMed: 16763912]

289. Oertel M, Shafritz DA. Stem cells, cell transplantation and liver repopulation. Biochim Biophys Acta. 2008; 1782(2):61-74. [PubMed: 18187050]

290. Petersen BE, Bowen WC, Patrene KD, Mars WM, Sullivan AK, Murase N, Boggs SS, Greenberger JS, Goff JP. Bone marrow as a potential source of hepatic oval cells. Science. 1999; 284(5417):1168-70. [PubMed: 10325227]

291. Lagasse E, Connors H, Al-Dhalimy M, Reitsma M, Dohse M, Osborne L, Wang X, Finegold M, Weissman IL, Grompe M. Purified hematopoietic stem cells can differentiate into hepatocytes in vivo. Nat Med. 2000; 6(11):1229-34. [PubMed: 11062533]

292. Vassilopoulos G, Wang PR, Russell DW. Transplanted bone marrow regenerates liver by cell fusion. Nature. 2003; 422(6934):901-4. [PubMed: 12665833]

293. Jang YY, Collector MI, Baylin SB, Diehl AM, Sharkis SJ. Hematopoietic stem cells convert into liver cells within days without fusion. Nat Cell Biol. 2004; 6(6):532-9. [PubMed: 15133469]

294. Kollet O, Shivtiel S, Chen YQ, Suriawinata J, Thung SN, Dabeva MD, Kahn J, Spiegel A, Dar A, Samira S, Goichberg P, Kalinkovich A, Arenzana-Seisdedos F, Nagler A, Hardan I, Revel M, Shafritz DA, Lapidot T. HGF, SDF-1, and MMP-9 are involved in stress-induced human CD34+ stem cell recruitment to the liver. J Clin Invest. 2003; 112(2):160-9. [PubMed: 12865405]

295. Krause DS, Theise ND, Collector MI, Henegariu O, Hwang S, Gardner R, Neutzel S, Sharkis SJ. Multi-organ, multi-lineage engraftment by a single bone marrow-derived stem cell. Cell. 2001; 105(3):369-77. [PubMed: 11348593]

296. Mallet VO, Mitchell C, Mezey E, Fabre M, Guidotti JE, Renia L, Coulombel L, Kahn A, Gilgenkrantz $\mathrm{H}$. Bone marrow transplantation in mice leads to a minor population of hepatocytes that can be selectively amplified in vivo. Hepatology. 2002; 35(4):799-804. [PubMed: 11915025]

297. Newsome PN, Johannessen I, Boyle S, Dalakas E, McAulay KA, Samuel K, Rae F, Forrester L, Turner ML, Hayes PC, Harrison DJ, Bickmore WA, Plevris JN. Human cord blood-derived cells can differentiate into hepatocytes in the mouse liver with no evidence of cellular fusion. Gastroenterology. 2003; 124(7):1891-900. [PubMed: 12806622]

298. Popp FC, Piso P, Schlitt HJ, Dahlke MH. Therapeutic potential of bone marrow stem cells for liver diseases. Curr Stem Cell Res Ther. 2006; 1(3):411-8. [PubMed: 18220884]

299. Sharma AD, Cantz T, Richter R, Eckert K, Henschler R, Wilkens L, Jochheim-Richter A, Arseniev L, Ott M. Human cord blood stem cells generate human cytokeratin 18-negative hepatocyte-like cells in injured mouse liver. Am J Pathol. 2005; 167(2):555-64. [PubMed: 16049339]

300. Theise ND, Krause DS. Bone marrow to liver: the blood of Prometheus. Semin Cell Dev Biol. 2002; 13(6):411-7. [PubMed: 12468241]

301. Wang X, Ge S, McNamara G, Hao QL, Crooks GM, Nolta JA. Albumin-expressing hepatocytelike cells develop in the livers of immune-deficient mice that received transplants of highly purified human hematopoietic stem cells. Blood. 2003; 101(10):4201-8. [PubMed: 12560238]

302. Wang X, Montini E, Al-Dhalimy M, Lagasse E, Finegold M, Grompe M. Kinetics of liver repopulation after bone marrow transplantation. Am J Pathol. 2002; 161(2):565-74. [PubMed: 12163381]

303. Eggenhofer E, Popp FC, Renner P, Slowik P, Neuwinger A, Piso P, Geissler EK, Schlitt HJ, Dahlke MH. Allogeneic bone marrow transplantation restores liver function in Fah-knockout mice. Exp Hematol. 2008; 36(11):1507-13. [PubMed: 18715687]

304. Fox IJ, Strom SC. To be or not to be: generation of hepatocytes from cells outside the liver. Gastroenterology. 2008; 134(3):878-81. [PubMed: 18325397]

305. Theise ND, Krause DS, Sharkis S. Comment on "Little evidence for developmental plasticity of adult hematopoietic stem cells". Science. 2003; 299(5611):1317. author reply 1317. [PubMed: 12610282]

306. Ishikawa F, Drake CJ, Yang S, Fleming P, Minamiguchi H, Visconti RP, Crosby CV, Argraves WS, Harada M, Key LL Jr, Livingston AG, Wingard JR, Ogawa M. Transplanted human cord 
blood cells give rise to hepatocytes in engrafted mice. Ann N Y Acad Sci. 2003; 996:174-85. [PubMed: 12799295]

307. Wang X, Willenbring H, Akkari Y, Torimaru Y, Foster M, Al-Dhalimy M, Lagasse E, Finegold M, Olson S, Grompe M. Cell fusion is the principal source of bone-marrow-derived hepatocytes. Nature. 2003; 422(6934):897-901. [PubMed: 12665832]

308. Muraca M, Ferraresso C, Vilei MT, Granato A, Quarta M, Cozzi E, Rugge M, Pauwelyn KA, Caruso M, Avital I, Inderbitzin D, Demetriou AA, Forbes SJ, Realdi G. Liver repopulation with bone marrow derived cells improves the metabolic disorder in the Gunn rat. Gut. 2007; 56(12): 1725-35. [PubMed: 17641081]

309. Theise ND, Badve S, Saxena R, Henegariu O, Sell S, Crawford JM, Krause DS. Derivation of hepatocytes from bone marrow cells in mice after radiation-induced myeloablation. Hepatology. 2000; 31(1):235-40. [PubMed: 10613752]

310. Almeida-Porada G, Porada CD, Chamberlain J, Torabi A, Zanjani ED. Formation of human hepatocytes by human hematopoietic stem cells in sheep. Blood. 2004; 104(8):2582-90. [PubMed: 15231580]

311. Almeida-Porada G, Zanjani ED. A large animal noninjury model for study of human stem cell plasticity. Blood Cells Mol Dis. 2004; 32(1):77-81. [PubMed: 14757417]

312. Porada GA, Porada C, Zanjani ED. The fetal sheep: a unique model system for assessing the full differentiative potential of human stem cells. Yonsei Med J. 2004; 45(Suppl):7-14. [PubMed: 15250043]

313. Almeida-Porada G, Zanjani ED, Porada CD. Bone marrow stem cells and liver regeneration. Exp Hematol. 2010; 38(7):574-80. [PubMed: 20417684]

314. Quintana-Bustamante O, Alvarez-Barrientos A, Kofman AV, Fabregat I, Bueren JA, Theise ND, Segovia JC. Hematopoietic mobilization in mice increases the presence of bone marrow-derived hepatocytes via in vivo cell fusion. Hepatology. 2006; 43(1):108-16. [PubMed: 16374873]

315. Tang XP, Zhang M, Yang X, Chen LM, Zeng Y. Differentiation of human umbilical cord blood stem cells into hepatocytes in vivo and in vitro. World J Gastroenterol. 2006; 12(25):4014-9. [PubMed: 16810750]

316. Colletti EJ, Airey JA, Liu W, Simmons PJ, Zanjani ED, Porada CD, Almeida-Porada G. Generation of tissue-specific cells from MSC does not require fusion or donor-to-host mitochondrial/membrane transfer. Stem cell research. 2009; 2(2):125-38. [PubMed: 19383418]

317. Kallis YN, Alison MR, Forbes SJ. Bone marrow stem cells and liver disease. Gut. 2007; 56(5): 716-24. [PubMed: 17145739]

318. Camargo FD, Finegold M, Goodell MA. Hematopoietic myelomonocytic cells are the major source of hepatocyte fusion partners. J Clin Invest. 2004; 113(9):1266-70. [PubMed: 15124017]

319. Lysy PA, Campard D, Smets F, Najimi M, Sokal EM. Stem cells for liver tissue repair: current knowledge and perspectives. World J Gastroenterol. 2008; 14(6):864-75. [PubMed: 18240343]

320. Willenbring H, Bailey AS, Foster M, Akkari Y, Dorrell C, Olson S, Finegold M, Fleming WH, Grompe M. Myelomonocytic cells are sufficient for therapeutic cell fusion in liver. Nat Med. 2004; 10(7):744-8. [PubMed: 15195088]

321. Enns GM, Millan MT. Cell-based therapies for metabolic liver disease. Mol Genet Metab. 2008; 95(1-2):3-10. [PubMed: 18640065]

322. Kim JK, Park YN, Kim JS, Park MS, Paik YH, Seok JY, Chung YE, Kim HO, Kim KS, Ahn SH, Kim do Y, Kim MJ, Lee KS, Chon CY, Kim SJ, Terai S, Sakaida I, Han KH. Autologous bone marrow infusion activates the progenitor cell compartment in patients with advanced liver cirrhosis. Cell Transplant. 2010; 19(10):1237-46. [PubMed: 20525430]

323. Lyra AC, Soares MB, da Silva LF, Braga EL, Oliveira SA, Fortes MF, Silva AG, Brustolim D, Genser B, Dos Santos RR, Lyra LG. Infusion of autologous bone marrow mononuclear cells through hepatic artery results in a short-term improvement of liver function in patients with chronic liver disease: a pilot randomized controlled study. Eur J Gastroenterol Hepatol. 2010; 22(1):33-42. [PubMed: 19654548]

324. Lyra AC, Soares MB, da Silva LF, Fortes MF, Silva AG, Mota AC, Oliveira SA, Braga EL, de Carvalho WA, Genser B, dos Santos RR, Lyra LG. Feasibility and safety of autologous bone 
marrow mononuclear cell transplantation in patients with advanced chronic liver disease. World J Gastroenterol. 2007; 13(7):1067-73. [PubMed: 17373741]

325. Saito T, Okumoto K, Haga H, Nishise Y, Ishii R, Sato C, Watanabe H, Okada A, Ikeda M, Togashi H, Ishikawa T, Terai S, Sakaida I, Kawata S. Potential therapeutic application of intravenous autologous bone marrow infusion in patients with alcoholic liver cirrhosis. Stem Cells Dev. 2011; 20(9):1503-10. [PubMed: 21417817]

326. Spahr L, Chalandon Y, Terraz S, Kindler V, Rubbia-Brandt L, Frossard JL, Breguet R, Lanthier N, Farina A, Passweg J, Becker CD, Hadengue A. Autologous bone marrow mononuclear cell transplantation in patients with decompensated alcoholic liver disease: a randomized controlled trial. PLoS One. 2013; 8(1):e53719. [PubMed: 23341981]

327. Terai S, Ishikawa T, Omori K, Aoyama K, Marumoto Y, Urata Y, Yokoyama Y, Uchida K, Yamasaki T, Fujii Y, Okita K, Sakaida I. Improved liver function in patients with liver cirrhosis after autologous bone marrow cell infusion therapy. Stem Cells. 2006; 24(10):2292-8. [PubMed: 16778155]

328. Gordon MY, Levicar N, Pai M, Bachellier P, Dimarakis I, Al-Allaf F, M'Hamdi H, Thalji T, Welsh JP, Marley SB, Davies J, Dazzi F, Marelli-Berg F, Tait P, Playford R, Jiao L, Jensen S, Nicholls JP, Ayav A, Nohandani M, Farzaneh F, Gaken J, Dodge R, Alison M, Apperley JF, Lechler R, Habib NA. Characterization and clinical application of human CD34+ stem/progenitor cell populations mobilized into the blood by granulocyte colony-stimulating factor. Stem Cells. 2006; 24(7):1822-30. [PubMed: 16556705]

329. Levicar N, Pai M, Habib NA, Tait P, Jiao LR, Marley SB, Davis J, Dazzi F, Smadja C, Jensen SL, Nicholls JP, Apperley JF, Gordon MY. Long-term clinical results of autologous infusion of mobilized adult bone marrow derived CD34+ cells in patients with chronic liver disease. Cell Prolif. 2008; 41(Suppl 1):115-25. [PubMed: 18181952]

330. Mohamadnejad M, Namiri M, Bagheri M, Hashemi SM, Ghanaati H, Zare Mehrjardi N, Kazemi Ashtiani S, Malekzadeh R, Baharvand H. Phase 1 human trial of autologous bone marrowhematopoietic stem cell transplantation in patients with decompensated cirrhosis. World $\mathbf{J}$ Gastroenterol. 2007; 13(24):3359-63. [PubMed: 17659676]

331. Pai M, Zacharoulis D, Milicevic MN, Helmy S, Jiao LR, Levicar N, Tait P, Scott M, Marley SB, Jestice K, Glibetic M, Bansi D, Khan SA, Kyriakou D, Rountas C, Thillainayagam A, Nicholls JP, Jensen S, Apperley JF, Gordon MY, Habib NA. Autologous infusion of expanded mobilized adult bone marrow-derived CD34+ cells into patients with alcoholic liver cirrhosis. Am J Gastroenterol. 2008; 103(8):1952-8. [PubMed: 18637092]

332. Gaia S, Smedile A, Omede P, Olivero A, Sanavio F, Balzola F, Ottobrelli A, Abate ML, Marzano A, Rizzetto M, Tarella C. Feasibility and safety of G-CSF administration to induce bone marrowderived cells mobilization in patients with end stage liver disease. J Hepatol. 2006; 45(1):13-9. [PubMed: 16635534]

333. Garg V, Garg H, Khan A, Trehanpati N, Kumar A, Sharma BC, Sakhuja P, Sarin SK. Granulocyte colony-stimulating factor mobilizes CD34(+) cells and improves survival of patients with acuteon-chronic liver failure. Gastroenterology. 2012; 142(3):505-512 e1. [PubMed: 22119930]

334. Han Y, Yan L, Han G, Zhou X, Hong L, Yin Z, Zhang X, Wang S, Wang J, Sun A, Liu Z, Xie H, Wu K, Ding J, Fan D. Controlled trials in hepatitis B virus-related decompensate liver cirrhosis: peripheral blood monocyte transplant versus granulocyte-colony-stimulating factor mobilization therapy. Cytotherapy. 2008; 10(4):390-6. [PubMed: 18574771]

335. Khan AA, Parveen N, Mahaboob VS, Rajendraprasad A, Ravindraprakash HR, Venkateswarlu J, Rao SG, Narusu ML, Khaja MN, Pramila R, Habeeb A, Habibullah CM. Safety and efficacy of autologous bone marrow stem cell transplantation through hepatic artery for the treatment of chronic liver failure: a preliminary study. Transplant Proc. 2008; 40(4):1140-4. [PubMed: 18555134]

336. Yan L, Han Y, Wang J, Liu J, Hong L, Fan D. Peripheral blood monocytes from patients with HBV related decompensated liver cirrhosis can differentiate into functional hepatocytes. Am J Hematol. 2007; 82(11):949-54. [PubMed: 17724706]

337. Yannaki E, Anagnostopoulos A, Kapetanos D, Xagorari A, Iordanidis F, Batsis I, Kaloyannidis P, Athanasiou E, Dourvas G, Kitis G, Fassas A. Lasting amelioration in the clinical course of 
decompensated alcoholic cirrhosis with boost infusions of mobilized peripheral blood stem cells. Exp Hematol. 2006; 34(11):1583-7. [PubMed: 17046578]

338. Eglitis MA, Mezey E. Hematopoietic cells differentiate into both microglia and macroglia in the brains of adult mice. Proc Natl Acad Sci U S A. 1997; 94(8):4080-5. [PubMed: 9108108]

339. Brazelton TR, Rossi FM, Keshet GI, Blau HM. From marrow to brain: expression of neuronal phenotypes in adult mice. Science. 2000; 290(5497):1775-9. [PubMed: 11099418]

340. Mezey E, Chandross KJ, Harta G, Maki RA, McKercher SR. Turning blood into brain: cells bearing neuronal antigens generated in vivo from bone marrow. Science. 2000; 290(5497):177982. [PubMed: 11099419]

341. Roybon L, Ma Z, Asztely F, Fosum A, Jacobsen SE, Brundin P, Li JY. Failure of transdifferentiation of adult hematopoietic stem cells into neurons. Stem Cells. 2006; 24(6): 1594-604. [PubMed: 16556707]

342. Barbosa da Fonseca LM, Gutfilen B, Rosado de Castro PH, Battistella V, Goldenberg RC, KasaiBrunswick T, Chagas CL, Wajnberg E, Maiolino A, Salles Xavier S, Andre C, Mendez-Otero R, de Freitas GR. Migration and homing of bone-marrow mononuclear cells in chronic ischemic stroke after intra-arterial injection. Exp Neurol. 2010; 221(1):122-8. [PubMed: 19853605]

343. Battistella V, de Freitas GR, da Fonseca LM, Mercante D, Gutfilen B, Goldenberg RC, Dias JV, Kasai-Brunswick TH, Wajnberg E, Rosado-de-Castro PH, Alves-Leon SV, Mendez-Otero R, Andre C. Safety of autologous bone marrow mononuclear cell transplantation in patients with nonacute ischemic stroke. Regen Med. 2011; 6(1):45-52. [PubMed: 21175286]

344. Prasad K, Mohanty S, Bhatia R, Srivastava MV, Garg A, Srivastava A, Goyal V, Tripathi M, Kumar A, Bal C, Vij A, Mishra NK. Autologous intravenous bone marrow mononuclear cell therapy for patients with subacute ischaemic stroke: a pilot study. Indian J Med Res. 2012; 136(2):221-8. [PubMed: 22960888]

345. Rosado-de-Castro PH, da Schmidt FR, Battistella V, Lopes de Souza SA, Gutfilen B, Goldenberg RC, Kasai-Brunswick TH, Vairo L, Silva RM, Wajnberg E, Alvarenga Americano do Brasil PE, Gasparetto EL, Maiolino A, Alves-Leon SV, Andre C, Mendez-Otero R, Rodriguez de Freitas G, Barbosa da Fonseca LM. Biodistribution of bone marrow mononuclear cells after intra-arterial or intravenous transplantation in subacute stroke patients. Regen Med. 2013; 8(2):145-55. [PubMed: 23477395]

346. Sprigg N, Bath PM, Zhao L, Willmot MR, Gray LJ, Walker MF, Dennis MS, Russell N. Granulocyte-colony-stimulating factor mobilizes bone marrow stem cells in patients with subacute ischemic stroke: the Stem cell Trial of recovery EnhanceMent after Stroke (STEMS) pilot randomized, controlled trial (ISRCTN 16784092). Stroke. 2006; 37(12):2979-83. [PubMed: 17082474]

347. Suarez-Monteagudo C, Hernandez-Ramirez P, Alvarez-Gonzalez L, Garcia-Maeso I, de la Cuetara-Bernal K, Castillo-Diaz L, Bringas-Vega ML, Martinez-Aching G, Morales-Chacon LM, Baez-Martin MM, Sanchez-Catasus C, Carballo-Barreda M, Rodriguez-Rojas R, GomezFernandez L, Alberti-Amador E, Macias-Abraham C, Balea ED, Rosales LC, Del Valle Perez L, Ferrer BB, Gonzalez RM, Bergado JA. Autologous bone marrow stem cell neurotransplantation in stroke patients. An open study. Restor Neurol Neurosci. 2009; 27(3):151-61. [PubMed: 19531871]

348. England TJ, Abaei M, Auer DP, Lowe J, Jones DR, Sare G, Walker M, Bath PM. Granulocytecolony stimulating factor for mobilizing bone marrow stem cells in subacute stroke: the stem cell trial of recovery enhancement after stroke 2 randomized controlled trial. Stroke. 2012; 43(2): 405-11. [PubMed: 22198983]

349. Chen J, Venkat P, Zacharek A, Chopp M. Neurorestorative therapy for stroke. Front Hum Neurosci. 2014; 8:382. [PubMed: 25018718]

350. Rosenkranz K, Kumbruch S, Lebermann K, Marschner K, Jensen A, Dermietzel R, Meier C. The chemokine SDF-1/CXCL12 contributes to the 'homing' of umbilical cord blood cells to a hypoxic-ischemic lesion in the rat brain. J Neurosci Res. 2010; 88(6):1223-33. [PubMed: 19937807]

351. Rosenkranz K, Kumbruch S, Tenbusch M, Marcus K, Marschner K, Dermietzel R, Meier C. Transplantation of human umbilical cord blood cells mediated beneficial effects on apoptosis, 
angiogenesis and neuronal survival after hypoxic-ischemic brain injury in rats. Cell Tissue Res. 2012; 348(3):429-38. [PubMed: 22526623]

352. Rosenkranz K, Meier C. Umbilical cord blood cell transplantation after brain ischemia--from recovery of function to cellular mechanisms. Ann Anat. 2011; 193(4):371-9. [PubMed: 21514122]

353. Vendrame M, Cassady J, Newcomb J, Butler T, Pennypacker KR, Zigova T, Sanberg CD, Sanberg PR, Willing AE. Infusion of human umbilical cord blood cells in a rat model of stroke dosedependently rescues behavioral deficits and reduces infarct volume. Stroke. 2004; 35(10):2390-5. [PubMed: 15322304]

354. Vendrame M, Gemma C, de Mesquita D, Collier L, Bickford PC, Sanberg CD, Sanberg PR, Pennypacker KR, Willing AE. Anti-inflammatory effects of human cord blood cells in a rat model of stroke. Stem Cells Dev. 2005; 14(5):595-604. [PubMed: 16305344]

355. Yan T, Venkat P, Ye X, Chopp M, Zacharek A, Ning R, Cui Y, Roberts C, Kuzmin-Nichols N, Sanberg CD, Chen J. HUCBCs increase angiopoietin 1 and induce neurorestorative effects after stroke in T1DM rats. CNS Neurosci Ther. 2014; 20(10):935-44. [PubMed: 25042092]

356. Acosta SA, Franzese N, Staples M, Weinbren NL, Babilonia M, Patel J, Merchant N, Simancas AJ, Slakter A, Caputo M, Patel M, Franyuti G, Franzblau MH, Suarez L, Gonzales-Portillo C, Diamandis T, Shinozuka K, Tajiri N, Sanberg PR, Kaneko Y, Miller LW, Borlongan CV. Human Umbilical Cord Blood for Transplantation Therapy in Myocardial Infarction. J Stem Cell Res Ther. 2013; (Suppl 4)

357. Bhakta S, Greco NJ, Finney MR, Scheid PE, Hoffman RD, Joseph ME, Banks JJ, Laughlin MJ, Pompili VJ. The safety of autologous intracoronary stem cell injections in a porcine model of chronic myocardial ischemia. J Invasive Cardiol. 2006; 18(5):212-8. [PubMed: 16670448]

358. Greco N, Laughlin MJ. Umbilical cord blood stem cells for myocardial repair and regeneration. Methods Mol Biol. 2010; 660:29-52. [PubMed: 20680811]

359. Henning RJ, Abu-Ali H, Balis JU, Morgan MB, Willing AE, Sanberg PR. Human umbilical cord blood mononuclear cells for the treatment of acute myocardial infarction. Cell Transplant. 2004; 13(7-8):729-39. [PubMed: 15690974]

360. Henning RJ, Burgos JD, Ondrovic L, Sanberg P, Balis J, Morgan MB. Human umbilical cord blood progenitor cells are attracted to infarcted myocardium and significantly reduce myocardial infarction size. Cell Transplant. 2006; 15(7):647-58. [PubMed: 17176616]

361. Henning RJ, Burgos JD, Vasko M, Alvarado F, Sanberg CD, Sanberg PR, Morgan MB. Human cord blood cells and myocardial infarction: effect of dose and route of administration on infarct size. Cell Transplant. 2007; 16(9):907-17. [PubMed: 18293889]

362. Henning RJ, Shariff M, Eadula U, Alvarado F, Vasko M, Sanberg PR, Sanberg CD, Delostia V. Human cord blood mononuclear cells decrease cytokines and inflammatory cells in acute myocardial infarction. Stem Cells Dev. 2008; 17(6):1207-19. [PubMed: 18393684]

363. Ma N, Ladilov Y, Kaminski A, Piechaczek C, Choi YH, Li W, Steinhoff G, Stamm C. Umbilical cord blood cell transplantation for myocardial regeneration. Transplant Proc. 2006; 38(3):771-3. [PubMed: 16647467]

364. Ma N, Ladilov Y, Moebius JM, Ong L, Piechaczek C, David A, Kaminski A, Choi YH, Li W, Egger D, Stamm C, Steinhoff G. Intramyocardial delivery of human CD133+ cells in a SCID mouse cryoinjury model: Bone marrow vs. cord blood-derived cells. Cardiovasc Res. 2006; 71(1):158-69. [PubMed: 16730684]

365. Ma N, Stamm C, Kaminski A, Li W, Kleine HD, Muller-Hilke B, Zhang L, Ladilov Y, Egger D, Steinhoff G. Human cord blood cells induce angiogenesis following myocardial infarction in NOD/scid-mice. Cardiovasc Res. 2005; 66(1):45-54. [PubMed: 15769447]

366. Norol F, Bonnet N, Peinnequin A, Chretien F, Legrand R, Isnard R, Herodin F, Baillou C, Delache B, Negre D, Klatzmann D, Vernant JP, Lemoine FM. GFP-transduced CD34+ and LinCD34- hematopoietic stem cells did not adopt a cardiac phenotype in a nonhuman primate model of myocardial infarct. Exp Hematol. 2007; 35(4):653-61. [PubMed: 17379075]

367. Schlechta B, Wiedemann D, Kittinger C, Jandrositz A, Bonaros NE, Huber JC, Preisegger KH, Kocher AA. Ex-vivo expanded umbilical cord blood stem cells retain capacity for myocardial regeneration. Circ J. 2010; 74(1):188-94. [PubMed: 19926917] 
368. Sondergaard CS, Hess DA, Maxwell DJ, Weinheimer C, Rosova I, Creer MH, Piwnica-Worms D, Kovacs A, Pedersen L, Nolta JA. Human cord blood progenitors with high aldehyde dehydrogenase activity improve vascular density in a model of acute myocardial infarction. $\mathbf{J}$ Transl Med. 2010; 8:24. [PubMed: 20214792]

369. Templin C, Kotlarz D, Faulhaber J, Schnabel S, Grote K, Salguero G, Luchtefeld M, Hiller KH, Jakob P, Naim HY, Schieffer B, Hilfiker-Kleiner D, Landmesser U, Limbourg FP, Drexler H. Ex vivo expanded hematopoietic progenitor cells improve cardiac function after myocardial infarction: role of beta-catenin transduction and cell dose. J Mol Cell Cardiol. 2008; 45(3):394403. [PubMed: 18671980]

370. Tseng A, Stabila J, McGonnigal B, Yano N, Yang MJ, Tseng YT, Davol PA, Lum LG, Padbury JF, Zhao TC. Effect of disruption of Akt-1 of lin(-)c-kit(+) stem cells on myocardial performance in infarcted heart. Cardiovasc Res. 2010; 87(4):704-12. [PubMed: 20410290]

371. Yoshioka T, Ageyama N, Shibata H, Yasu T, Misawa Y, Takeuchi K, Matsui K, Yamamoto K, Terao K, Shimada K, Ikeda U, Ozawa K, Hanazono Y. Repair of infarcted myocardium mediated by transplanted bone marrow-derived CD34+ stem cells in a nonhuman primate model. Stem Cells. 2005; 23(3):355-64. [PubMed: 15749930]

372. Zhao TC, Tseng A, Yano N, Tseng Y, Davol PA, Lee RJ, Lum LG, Padbury JF. Targeting human CD34+ hematopoietic stem cells with anti-CD45 $\mathrm{x}$ anti-myosin light-chain bispecific antibody preserves cardiac function in myocardial infarction. J Appl Physiol (1985). 2008; 104(6):1793800. [PubMed: 18292296]

373. Orlic D, Kajstura J, Chimenti S, Bodine DM, Leri A, Anversa P. Transplanted adult bone marrow cells repair myocardial infarcts in mice. Ann N Y Acad Sci. 2001; 938:221-9. discussion 229_ 30. [PubMed: 11458511]

374. Orlic D, Kajstura J, Chimenti S, Bodine DM, Leri A, Anversa P. Bone marrow stem cells regenerate infarcted myocardium. Pediatr Transplant. 2003; 7(Suppl 3):86-8. [PubMed: 12603699]

375. Orlic D, Kajstura J, Chimenti S, Jakoniuk I, Anderson SM, Li B, Pickel J, McKay R, NadalGinard B, Bodine DM, Leri A, Anversa P. Bone marrow cells regenerate infarcted myocardium. Nature. 2001; 410(6829):701-5. [PubMed: 11287958]

376. Achilli F, Malafronte C, Lenatti L, Gentile F, Dadone V, Gibelli G, Maggiolini S, Squadroni L, Di Leo C, Burba I, Pesce M, Mircoli L, Capogrossi MC, Di Lelio A, Camisasca P, Morabito A, Colombo G, Pompilio G, Investigators SA. Granulocyte colony-stimulating factor attenuates left ventricular remodelling after acute anterior STEMI: results of the single-blind, randomized, placebo-controlled multicentre STem cEll Mobilization in Acute Myocardial Infarction (STEMAMI) Trial. Eur J Heart Fail. 2010; 12(10):1111-21. [PubMed: 20861135]

377. Achilli F, Malafronte C, Maggiolini S, Lenatti L, Squadroni L, Gibelli G, Capogrossi MC, Dadone V, Gentile F, Bassetti B, Di Gennaro F, Camisasca P, Calchera I, Valagussa L, Colombo GI, Pompilio G. S.-A.t. Investigators. G-CSF treatment for STEMI: final 3-year follow-up of the randomised placebo-controlled STEM-AMI trial. Heart. 2014; 100(7):574-81. [PubMed: 24415665]

378. Gu X, Xie Y, Gu J, Sun L, He S, Xu R, Duan J, Zhao J, Hang F, Xu H, Li M, Cao K, Geng Y. Repeated intracoronary infusion of peripheral blood stem cells with G-CSF in patients with refractory ischemic heart failure--a pilot study. Circ J. 2011; 75(4):955-63. [PubMed: 21325723]

379. Honold J, Fischer-Rasokat U, Lehmann R, Leistner DM, Seeger FH, Schachinger V, Martin H, Dimmeler S, Zeiher AM, Assmus B. G-CSF stimulation and coronary reinfusion of mobilized circulating mononuclear proangiogenic cells in patients with chronic ischemic heart disease:fiveyear results of the TOPCARE-G-CSF trial. Cell Transplant. 2012; 21(11):2325-37. [PubMed: 22963750]

380. Kang HJ, Kim HS, Koo BK, Kim YJ, Lee D, Sohn DW, Oh BH, Park YB. Intracoronary infusion of the mobilized peripheral blood stem cell by G-CSF is better than mobilization alone by G-CSF for improvement of cardiac function and remodeling: 2-year follow-up results of the Myocardial Regeneration and Angiogenesis in Myocardial Infarction with G-CSF and Intra-Coronary Stem Cell Infusion (MAGIC Cell) 1 trial. Am Heart J. 2007; 153(2):237 e1-8. [PubMed: 17239682]

381. Kang HJ, Kim MK, Kim MG, Choi DJ, Yoon JH, Park YB, Kim HS. A multicenter, prospective, randomized, controlled trial evaluating the safety and efficacy of intracoronary cell infusion 
mobilized with granulocyte colony-stimulating factor and darbepoetin after acute myocardial infarction: study design and rationale of the 'MAGIC cell-5-combination cytokine trial'. Trials. 2011; 12(1):33. [PubMed: 21299845]

382. Kang HJ, Kim MK, Lee HY, Park KW, Lee W, Cho YS, Koo BK, Choi DJ, Park YB, Kim HS. Five-year results of intracoronary infusion of the mobilized peripheral blood stem cells by granulocyte colony-stimulating factor in patients with myocardial infarction. Eur Heart J. 2012; 33(24):3062-9. [PubMed: 22904565]

383. Kang HJ, Yoon EJ, Lee EJ, Kim MK, Suh JW, Park KW, Lee HY, Park KU, Cho YS, Koo BK, Chae IH, Choi DJ, Han KS, Kim HS, Park YB. Cotreatment with darbepoetin and granulocyte colony-stimulating factor is efficient to recruit proangiogenic cell populations in patients with acute myocardial infarction. Cell Transplant. 2012; 21(5):1055-61. [PubMed: 22449332]

384. Karimabad HM, Shabestari M, Baharvand H, Vosough A, Gourabi H, Shahverdi A, Shamsian A, Abdolhoseini S, Moazzami K, Marjanimehr MM, Emami F, Bidkhori HR, Hamedanchi A, Talebi S, Farrokhi F, Jabbari-Azad F, Fadavi M, Garivani U, Mahmoodi M, Aghdami N. Lack of beneficial effects of granulocyte colony-stimulating factor in patients with subacute myocardial infarction undergoing late revascularization: a double-blind, randomized, placebo-controlled clinical trial. Acta Cardiol. 2011; 66(2):219-24. [PubMed: 21591581]

385. Leone AM, Galiuto L, Garramone B, Rutella S, Giannico MB, Brugaletta S, Perfetti M, Liuzzo G, Porto I, Burzotta F, Niccoli G, Biasucci LM, Leone G, Rebuzzi AG, Crea F. Usefulness of granulocyte colony-stimulating factor in patients with a large anterior wall acute myocardial infarction to prevent left ventricular remodeling (the rigenera study). Am J Cardiol. 2007; 100(3): 397-403. [PubMed: 17659916]

386. Malafronte C, Achilli F. Stem cells mobilization in acute myocardial infarction (stem-AMI trial): preliminary data of a perspective, randomized, single blind trial. Minerva Cardioangiol. 2007; 55(6):721-31. [PubMed: 18091641]

387. Mozid AM, Jones D, Arnous S, Saunders N, Wragg A, Martin J, Agrawal S, Mathur A. The effects of age, disease state, and granulocyte colony-stimulating factor on progenitor cell count and function in patients undergoing cell therapy for cardiac disease. Stem Cells Dev. 2013; 22(2): 216-23. [PubMed: 22834565]

388. Overgaard M, Ripa RS, Wang Y, Jorgensen E, Kastrup J. Timing of granulocyte-colony stimulating factor treatment after acute myocardial infarction and recovery of left ventricular function: results from the STEMMI trial. Int J Cardiol. 2010; 140(3):351-5. [PubMed: 19131132]

389. Pasquet S, Sovalat H, Henon P, Bischoff N, Arkam Y, Ojeda-Uribe M, Bouar R, Rimelen V, Brink I, Dallemand R, Monassier JP. Long-term benefit of intracardiac delivery of autologous granulocyte-colony-stimulating factor-mobilized blood CD34+ cells containing cardiac progenitors on regional heart structure and function after myocardial infarct. Cytotherapy. 2009; 11(8):1002-15. [PubMed: 19929464]

390. Povsic TJ, Junge C, Nada A, Schatz RA, Harrington RA, Davidson CJ, Fortuin FD, Kereiakes DJ, Mendelsohn FO, Sherman W, Schaer GL, White CJ, Stewart D, Story K, Losordo DW, Henry TD. A phase 3, randomized, double-blinded, active-controlled, unblinded standard of care study assessing the efficacy and safety of intramyocardial autologous CD34+ cell administration in patients with refractory angina: design of the RENEW study. Am Heart J. 2013; 165(6):854-861 e2. [PubMed: 23708155]

391. Ripa RS, Haack-Sorensen M, Wang Y, Jorgensen E, Mortensen S, Bindslev L, Friis T, Kastrup J. Bone marrow derived mesenchymal cell mobilization by granulocyte-colony stimulating factor after acute myocardial infarction: results from the Stem Cells in Myocardial Infarction (STEMMI) trial. Circulation. 2007; 116(11 Suppl):I24-30. [PubMed: 17846310]

392. Santoso T, Irawan C, Alwi I, Aziz A, Kosasih A, Inggriani S, Saputra A, Wintery M, Lison L. Safety and feasibility of combined granulocyte colony stimulating factor and erythropoetin based-stem cell therapy using intracoronary infusion of peripheral blood stem cells in patients with recent anterior myocardial infarction: one-year follow-up of a phase 1 study. Acta Med Indones. 2011; 43(2):112-21. [PubMed: 21785174]

393. Steppich BA, Demetz G, Schulz S, von Wedel J, Pogatsa-Murray G, Braun SL, Stein A, Kastrati A, Schomig A, Ott I. Effects of G-CSF on systemic inflammation, coagulation and platelet 
activation in patients with acute myocardial infarction. Thromb Res. 2011; 127(2):119-21. [PubMed: 21095620]

394. Vrtovec B, Poglajen G, Lezaic L, Sever M, Domanovic D, Cernelc P, Socan A, Schrepfer S, Torre-Amione G, Haddad F, Wu JC. Effects of intracoronary CD34+ stem cell transplantation in nonischemic dilated cardiomyopathy patients: 5-year follow-up. Circ Res. 2013; 112(1):165-73. [PubMed: 23065358]

395. Yang C, Deng Z, Jiang X, Han K, Zhang T, Zhu W, Geng T, Chen X, Ma A. Long-term effects of primary early granulo-monocyte colony-stimulating factor treatment on the left ventricular function and remodeling in patients with acute myocardial infarction with five-year follow-up. Int J Cardiol. 2012; 155(2):287-90. [PubMed: 22222425]

396. Yeo C, Mathur A. Autologous bone marrow-derived stem cells for ischemic heart failure: REGENERATE-IHD trial. Regen Med. 2009; 4(1):119-27. [PubMed: 19105621]

397. Zohlnhofer D, Kastrati A, Schomig A. Stem cell mobilization by granulocyte-colony-stimulating factor in acute myocardial infarction: lessons from the REVIVAL-2 trial. Nat Clin Pract Cardiovasc Med. 2007; 4(Suppl 1):S106-9. [PubMed: 17230206]

398. Mund JA, Estes ML, Yoder MC, Ingram DA Jr, Case J. Flow cytometric identification and functional characterization of immature and mature circulating endothelial cells. Arterioscler Thromb Vasc Biol. 2012; 32(4):1045-53. [PubMed: 22282356]

399. Bryder D, Rossi DJ, Weissman IL. Hematopoietic stem cells: the paradigmatic tissue-specific stem cell. Am J Pathol. 2006; 169(2):338-46. [PubMed: 16877336] 


\section{Highlights}

- When scientists discovered that a rare population of stem cells present within the bone marrow maintains the entire adult hematopoietic system, the door was opened to the possibility of applying regenerative medicine to the field of hematology.

- The fact that the entire hematopoietic system can be repopulated following infusion of limited numbers of HSC makes it possible for HSC transplantation to treat/cure a range of hematologic diseases, including malignancies.

- Although HSC were first identified in and isolated from bone marrow, alternate sources of HSC such as mobilized peripheral blood and umbilical cord blood have many characteristics that make them well suited for clinical use. Moreover, with the advent of reprogramming technology, the development of methods to generate functional HSC from iPS cells promises to one day make it possible to generate unlimited numbers of perfectly matched, patient-specific HSC for therapy.

- For reasons that are poorly understood, the transplantation and engraftment of even low levels of HSC can render the recipient tolerant to the HSC donor. This phenomenon is now being exploited to combat autoimmune diseases and to reduce/eliminate the immune response to allogeneic solid organ grafts.

- A great deal of preclinical and clinical evidence over the last 10 years has shown that the transplantation of HSC can also exerts a therapeutic benefit in nonhematopoietic diseases of multiple organs, including the liver, heart, and brain. The mechanism whereby these cells exert their benefit is, however, still an area of intense debate. 